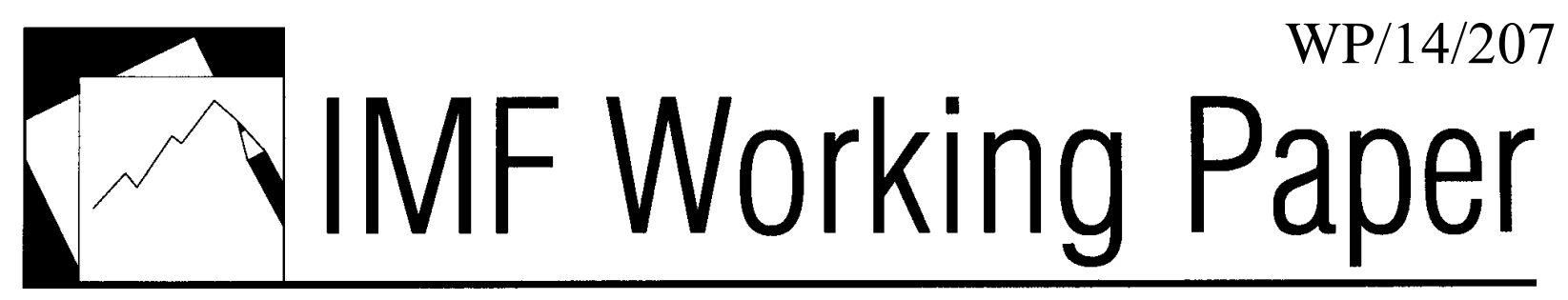

The Transmission of Liquidity Shocks:

\title{
The Role of Internal Capital Markets and Bank Funding Strategies
}

Philippe Karam, Ouarda Merrouche, Moez Souissi and Rima Turk 


\title{
IMF Working Paper
}

\section{Middle East Center for Economics and Finance}

\author{
The Transmission of Liquidity Shocks: \\ The Role of Internal Capital Markets and Bank Funding Strategies \\ Prepared by Philippe Karam, Ouarda Merrouche, Moez Souissi and Rima Turk \\ Authorized for distribution by Philippe Karam
}

November 2014

\section{This Working Paper should not be reported as representing the views of the IMF. The views expressed in this Working Paper are those of the author(s) and do not necessarily represent those of the IMF or IMF policy. Working Papers describe research in progress by the author(s) and are published to elicit comments and to further debate.}

\begin{abstract}
We analyze the transmission of bank-specific liquidity shocks triggered by a credit rating downgrade through the lending channel. Using bank-level data for US Bank Holding Companies, we find that a credit rating downgrade is associated with an immediate and persistent decline in access to non-core deposits and wholesale funding, especially during the global financial crisis. This translates into a reduction in lending to households and nonfinancial corporates at home and abroad. The effect on domestic lending, however, is mitigated when banks (i) hold a larger buffer of liquid assets, (ii) diversify away from rating-sensitive sources of funding, and (iii) activate internal liquidity support measures. Foreign lending is significantly reduced during a crisis at home only for subsidiaries with weak funding selfsufficiency.
\end{abstract}

JEL Classification Numbers: E51, F23, F34, F36, G21

Keywords: Credit ratings, Liquidity management, Credit supply, Multinational banks, Internal capital markets

Authors E-Mail Addresses: pkaram@imf.org, ouarda.merrouche@eui.eu, msouissi@imf.org, rturk@imf.org 
Abstract

I. Introduction

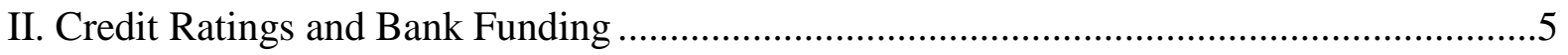

III. Identification Strategies ..................................................................................

A. Credit rating downgrade and external funding ............................................. 7

B. Credit rating downgrade, bank funding, and bank lending .................................

C. Credit rating downgrade, internal funding, and bank lending .............................10

IV. Data

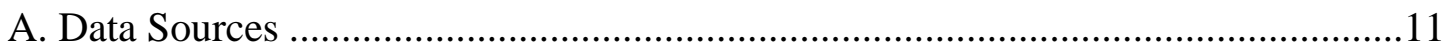

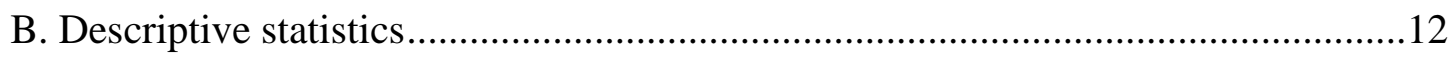

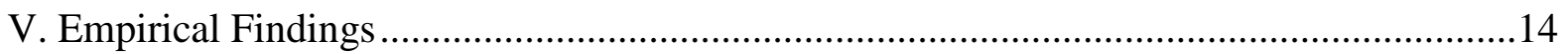

A. Downgrade and Access to External Funding ............................................... 14

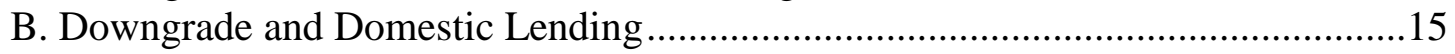

C. Downgrade and Foreign Lending............................................................... 16

D. Downgrade, Internal Funding Markets Activation, and Lending .........................16

VI. Further Tests and Robustness Checks .................................................................18

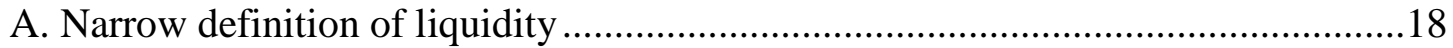

B. Commercial and Industrial (C\&I) Lending and Cross-Border Lending .................18

C. Controlling for Additional Observables and Alternative Matching Method ..........18

VII. Conclusion.

Tables

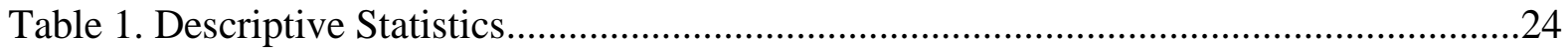

Table 2. Downgrade and External Funding ................................................................26

Table 3. Downgrade and Bank Funding: Core versus Non-Core Funding ............................28

Table 4. Downgrade, Domestic Lending, and Liquidity-Constrained Balance Sheets I .........29

Table 5. Downgrade, Domestic Lending, and Liquidity-Constrained Balance Sheets II........30

Table 6. Downgrade, Foreign Lending, and Self-Sufficiency ..........................................

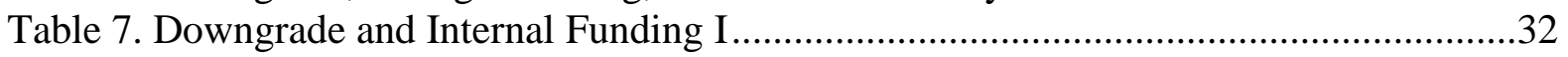

Table 8. Downgrade and Internal Funding II..................................................................33

Table 9. Downgrade, Internal Funding and Lending .........................................................34

Figures

Figure 1. Number of credit rating downgrades by quarter.................................................35

Figure 2. Average deposits and funding 4 quarters around a downgrade pre and post Q4-200836

Figure 3. Cumulative sum of changes in external and internal funding 4 quarters around .....37

Figure 4. Average effect of a credit rating downgrade on core and non-core funding for .......38

References

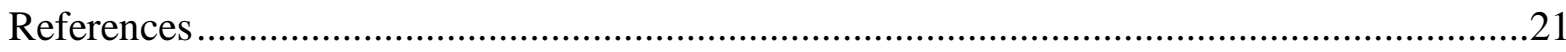




\section{INTRODUCTION ${ }^{1}$}

Should bank liquidity be regulated? If so how to implement liquidity regulation? This paper provides some elements of response to these questions. Liquidity regulation is an important part of the current international regulatory reform agenda. Policymakers have put forward the introduction of liquidity standards (along with capital standards) with the objective to promote the short term resilience of banks during liquidity crises and curb the risk of asset-fire sale spillovers and systemic risk. The desirability of liquidity regulation is rationalized by the observation that the use of the lender of last resort capacity during a crisis is socially costly: central banks necessarily assume additional credit risk (because the line between illiquid and insolvent institutions is blurred) and their interventions create moral hazard (Acharya and Tuckman, 2013). In addition, there is evidence that banks may be reluctant to tap central bank facilities when they need it most due to the higher stigma attached to using central bank facilities in a crisis (Armentier and others, 2013). Hence liquidity regulation is viewed by policymakers as a necessary complement to the lender of last resort function and to deposit insurance, particularly as bank funding increasingly extends beyond raising traditional deposits.

In this paper, evidence in favor of the introduction of liquidity regulation is presented. Using quarterly regulatory fillings of listed US Bank Holding Companies (BHCs) for the period 2000 to 2012, we assess the role of liquidity self-insurance in mitigating the impact of a liquidity shock on bank lending. We analyze the effects of a liquidity shock that is triggered by a credit rating downgrade, focusing on banks' access to external funding (in particular uninsured time deposits and wholesale funding) and the shock's transmission to bank lending at home and abroad. We give particular attention to the period of the global financial crisis when the US Federal Reserve massively stepped up liquidity support to banks and the Federal Deposit Insurance Corporation (FDIC) considerably expanded deposit insurance coverage.

This paper belongs to the nascent literature about the effect of rating downgrades on bank lending. A few studies have investigated the impact of sovereign downgrades on banks' supply of loans (Popov, A. and Van Horen, 2013; Angeloni and Wolff, 2012; and Arezki, Candelon and Sy, 2011). In this paper, we focus on bank-specific credit risk downgrades that occur because of changes in their own fundamentals. We also contribute to the literature by identifying bank funding liquidity as the transmission mechanism through which a rating downgrade can affect bank lending. Using bank-level data of US BHCs, we find that banks that experienced a credit rating downgrade also suffered from a simultaneous and persistent decline in access to non-core sources of deposits and to wholesale funding, which in turn translates into a significant decline in both domestic and foreign lending.

The paper also belongs to research on the international transmission of financial shocks at multinational banks through their internal capital markets. ${ }^{2}$ A number of studies find that internal capital markets are used by international banks to support their foreign affiliates during times of financial stress (Barba-Navaretti, Calzolari, Levi and Pozzolo, 2010; De Haas

\footnotetext{
${ }^{1}$ We are grateful for useful comments from participants at the annual seminar of the Research Department of the Bank of Finland, from Bradley Jones and Michael Papaioannou (IMF Monetary and Capital Markets Department), and from Hui Tong (IMF, Research Department). We also wish to thank Fatima Keaik (CEF) for her editorial support.

${ }^{2}$ Among others, Campello (2002), Ashcraft (2006, 2008), and Cetorelli and Goldberg (2012a) provide empirical evidence on the existence of active internal capital markets at multinational banks.
} 
and Van Lelyveld, 2010; and Schnabl, 2012). Others show that liquidity shocks at home can be transmitted abroad to banks' foreign subsidiaries with negative consequences on their lending activities. Giannetti and Laeven (2012a, 2012b) find that, following a banking crisis at home, banks that are active in the syndicated loan market reallocate capital towards domestic markets in a "flight to home effect", thereby transmitting negative shocks to the host country. There is also evidence from the great recession that foreign subsidiaries reduced their lending compared to domestic banks following episodes of liquidity problems at parent banks in the US (Acharya and Schnabl, 2010; Chava and Purnandam, 2011; and Cetorelli and Goldberg, 2012a) and in emerging European countries (Popov and Udel, 2010; De Haas, Korniyenko, Loukoianova and Pivovarsk, 2011). However, the transmission of shocks to affiliates is weaker for those locations considered as important investment locations and it is stronger for important funding locations (Cetorelli and Goldberg 2012c). De Haas and Van Horen (2011) find that, during the global crisis foreign banks continued to lend to those countries that were geographically close and with whom they have established long-term lending relationships, suggesting that foreign banks do differentiate between markets during times of stress. We contribute to this literature by showing that the international transmission of liquidity shocks on the supply of bank lending is tempered by holding a larger buffer of liquid assets. This finding is particularly true during a crisis when co-insurance between banks breaks down. Further, we report that foreign lending is unaffected by a parent bank downgrade when foreign subsidiaries are self-sufficient, meaning that they fund their loan portfolios through deposits in the host country.

This study also relates to the literature on capital allocation within firms, which argues that internal capital markets alleviate cash constraints of units with better investment prospects and therefore allow for a more efficient capital allocation (Stein, 1997). ${ }^{3}$ Along the same lines, bank affiliates may find it more efficient to transfer excess deposits to their parent banks to avail them for other members of the banking group that have better investment prospects and, in return, they get insulated from headquarters' idiosyncratic liquidity shocks (Houston, Marcus, and James, 1997; Campello, 2002; and Ashcraft, 2008). We examine a number of internal support measures that are activated following a downgrade of the parent bank, including downstream and upstream loans as well as downstream capital injections. We find that internal capital allocation at banks with centralized liquidity management marginally curbs the negative effects of a liquidity shock on bank lending, albeit proving insufficient to sustain bank lending during the recent financial crisis.

In the next section, we review the importance of credit ratings in financial markets. We then present the paper's empirical strategy followed by a presentation of the results and discussion of implications for policy.

\section{Credit Ratings And Bank Funding}

Ratings are an invaluable source of information for investors. They level-out the information asymmetry present in markets because credit rating agencies (CRAs) collect costly to acquire information that is not readily available to investors, which is expected to be integrated in their assessment of the creditworthiness of an issuer or a counterparty. Thus, they provide

\footnotetext{
${ }^{3}$ Another strand of the literature contends that internal capital markets can generate agency problems and power struggles within an organization, which in turn can lead to an inefficient allocation of resources (e.g. Rajan, Servaes, and Zingales, 2000).
} 
easy to understand, quick, and cheap information on the quality of a counterparty for nonsophisticated investors with limited resources. Receiving a rating also facilitates an issuer's access to funding from capital markets. ${ }^{4}$

The importance of ratings has received considerable attention in the literature. Kisgen (2006, 2009) finds that credit ratings directly affect firms' capital structure decisions. Kraft (2010) reports that rating agencies are reluctant to downgrade borrowers whose debt contracts have rating change triggers. Also, changes in bond ratings have a significant impact on stock prices (Jorion et al, 2005), trading volumes (Bailey et al, 2003), and the cost of equity capital (Durate et al, 2008). Morgan (2002) documents that bank ratings can differ across major raters and that disagreement increases with the average rating and issue maturity, but it decreases with issue size.

Ratings are used notably in interbank markets and derivatives markets where minimum ratings are required by internal procedures to determine the eligibility of a counterparty to participate in a transaction. If eligible, the rating will determine the terms of the transaction in these markets. ${ }^{5}$

As a consequence, a credit rating downgrade is potentially a serious threat to bank funding. There is abundant anecdotal evidence and reporting in the press that, during the global financial crisis, banks that were downgraded faced higher funding costs, higher collateral requirements, and they even lost access to markets due to rating triggers. In turn, restricted access to funding had material consequences on the ability of banks to extend credit to household and corporates.

Credit rating downgrades have an "immediate impact on the ability of money market funds to provide short-term financing to banks, because some clients stipulate that counterparties must have a minimum credit rating.... As a bank moves down the ratings ladder, some investors' mandates with clients will prohibit them from holding that bank's security." (Financial Times, May 21 2012).

"In the case of longer-term funds, most will set an exposure limit they have in a bank and some of the limitation will be dictated by credit ratings ...If a bank truly cannot access wholesale funding, then it should deleverage. In its first quarter report, FIH said that one of the measures it would take to tackle some of these funding issues would be to reduce its loan balance. (Reuters, June 28 2011)

"The cuts, which would follow downgrades by Standard \& Poor's and Fitch Ratings last year, could erode profits, trigger margin calls and leave some firms unable to borrow from money-market funds that have strict rules on who they can lend to. Without access to funding

\footnotetext{
${ }^{4}$ The literature shows that ratings incorporate information that is not imbedded in prices of bonds and stocks. West (1973) and Ederington, Yawitz, and Roberts (1987) find that credit ratings predict bond yields beyond the information contained in publicly available financial variables and other variables that predict spreads. Large firms that issue publicly held debt are also indispensable for managing interest costs and attracting investors (Liu et al., 1999).

${ }^{5}$ Many contracts contain triggers that activate if a bank rating falls below a predetermined level.
} 
from private sources, banks have had to sell assets and reduce lending." (Bloomberg, 9 May 2012)

"Credit ratings are particularly important for financial companies, which greatly depend on the confidence of their creditors and the companies they trade with. A high credit rating enables banks to put up less money, which they can borrow cheaply, while a lower credit rating can mean they have to put up more money and perhaps pay more for their loans ....If the short-term credit ratings of a parent company, bank or broker/dealer subsidiaries were downgraded by one or more levels, the potential loss of access to short-term funding sources such as repo financing could be material." (New York Times, 29 March 2012).

Since the advent of the crisis, the quality of ratings has been seriously called into question and CRAs have come under increasing scrutiny. There have been heightened concerns among policymakers that CRAs' decisions are subject to conflict of interest that led to the mispricing of mortgage-backed securities and the general misjudgment of counterparties' creditworthiness. CRAs are generally criticized for allocating too many resources to chasing new businesses and products rather than improving their analysis of existing segments due to wrong incentives. ${ }^{6}$ Assessing the quality of credit ratings and the risks that poor ratings create for the financial system are, however, beyond the scope of this paper. In what follows, we show that, despite growing discontent with CRAs, market participants have continued to rely heavily on credit ratings for their financing and investment decisions.

\section{IDENTIFICATION STRATEGIES}

Our analysis proceeds in three steps. First, we identify sources of funding at a BHC that are sensitive to a change in credit rating to establish the effect of a downgrade on bank funding liquidity. Next, we analyze the transmission effect of the downgrade-related funding liquidity shock to domestic and foreign lending. Last, we develop a framework to assess the role of internal capital markets in the propagation or the containment of funding liquidity shocks.

\section{A. Credit rating downgrade and external funding}

The first part of our analysis establishes the link between a rating downgrade and bank funding. ${ }^{7}$ We compare the change in the volume of wholesale funding and deposits of a downgraded bank (treated bank) one period after and one period before it is downgraded with that of a bank which is not downgraded (control bank) during the same period. ${ }^{8} \mathrm{~A}$ control bank has the same rating as the treated bank in the period preceding the downgrade and is not downgraded during the four subsequent periods.

The baseline cross-sectional ${ }^{9}$ regression reads as follows:

\footnotetext{
${ }^{6}$ Hau et al (2012) show that CRAs assign more positive ratings to large banks and institutions that are more likely to provide them with additional business.

${ }^{7}$ We acknowledge that there may be asymmetric effects for rating changes, but we only consider downgrades in this study.

${ }^{8}$ Each period is set as a quarter.

${ }^{9}$ Most banks in our sample experience only one downgrade.
} 


$$
\begin{aligned}
\Delta y_{i,(t-1, t+1)}= & c_{1}+\beta_{1} * \text { downgrade }_{i, t}+\beta_{2} * \text { downgrade }_{i, t} * T R_{i, t-1}+X_{i, t-1} \pi_{1} \\
& +\mu_{t-1}+\gamma_{t}+\varepsilon_{1 i, t}
\end{aligned}
$$

Where $\Delta y_{i,(t-1, t+1)}$ indicates the change in wholesale funding or deposits for bank $i$ between one period following the downgrade and one period preceding the downgrade, with $t$ denoting the time of the downgrade; downgrade $e_{i, t}$ is a dummy that takes value 1 if bank $i$ is a treated bank at time $t$ and 0 if it is a control bank; and $T R_{i, t-1}$ is another dummy that is set to 1 if the downgraded bank $i$ has a top rating of A- or higher one period before the downgrade, as its access to funding might be different from that of a lower-rated bank. ${ }^{10} X_{i, t-1}$ is a vector of control variables including the lagged dependent variable, its lagged level, and the lagged log of assets to account for the fact that size may affect market access due to "Too-Big-To-Fail" perception by market participants. $\mu_{t-1}$ and $\gamma_{t}$ are fixed effects for bank $i$ 's initial rating and time of downgrade. Hence, we compare a treated bank to a control bank that has the same initial rating within the same period $t$. In section 6 , we discuss the robustness of our results to including additional controls that would capture changes in both the demand and supply for funding and that are correlated with the likelihood of being downgraded.

The coefficient of interest is $\beta_{1}$, which captures the average effect of a downgrade:

$$
\hat{\beta}_{1}=E(\Delta y \mid(\text { downgrade }=1)-E(\Delta y \mid \text { downgrade }=0)
$$

We account for the anecdotal evidence that the effect of a downgrade may be tempered when the initial rating of the downgraded bank is A- or higher by interacting $T R_{i-1}$ with the variable downgrade $e_{i, t} \cdot{ }^{11,12,13}$ The partial term is captured by the initial rating fixed effects.

We run specification (1) on the full sample, on the period preceding the extension of the deposit insurance coverage from USD 100K to USD 250K that took place in October 2008 after the Lehman default, and the period following it. We expect a downgrade to have a stronger effect on deposit funding before Q4-2008 since the sensitivity of deposit funding to downgrades is higher when deposit insurance coverage is lower. We also predict a stronger effect on wholesale funding after and including Q4-2008, as the Lehman default triggered a severe seizure of interbank markets. In times of crisis, heightened asymmetric information about counterparty risk can severely impair interbank markets (Heider, Hoerova, and Holthausen, 2010). We argue that credit ratings level-out this asymmetric information as they potentially incorporate privileged information on counterparty risk. Further, Hau et al. (2012) show that the quality of credit ratings, that is their information content, increases during financial crises. For these reasons, we expect investors to be more responsive to a change in credit rating after the Lehman default and hence the effect of a downgrade on access to external funding to be more pronounced during that period.

\footnotetext{
${ }^{10}$ We only examine quantity effects associated with a downgrade, as data on cost of funding and lending rates by institution is not directly available.

11 "Once a bank gets into Triple B territory, it is no longer considered prime and those [money market] funds often can't invest in bank senior debt unless it is rated prime....”. Financial Times, May 212012

${ }^{12}$ Downgrades (...) will hit the weakest banks hardest, while giving lenders with the highest ratings, such as HSBC and JPMorgan, a competitive advantage in securing funding”, Bloomberg 9 May 2012

13 "It is very tricky to be a large trading bank with a rating below A" New York Times, 29 March 2012
} 


\section{B. Credit rating downgrade, bank funding, and bank lending}

Next we explore the transmission of the shock to domestic and foreign bank lending, $\Delta L$. We start by estimating the reduced-form effect of a downgrade on domestic lending using specification (1). Then we augment specification (1) to integrate the fact that the effect of a downgrade on domestic lending will be stronger for banks with a higher exposure to non-core sources of funding that are rating-sensitive (uninsured time deposits and other deposits not covered by US deposit insurance, fed funds, and repos). ${ }^{14}$ We estimate the new equation for constrained and unconstrained banks separately and for the full sample and during a period when wholesale markets are distressed. ${ }^{15}$

The extended specification reads:

$\Delta L_{i,(t-1, t+4)}=c_{2}+\alpha_{1} *$ downgrade ${ }_{i, t}+\alpha_{2} *$ downgrade $_{i, t} * T R_{i, t-1}+\alpha_{3} *$ downgradei, $t * H C R S t-1+$

$\alpha 4 *$ downgradei, $t * T R i, t-1 * H C R S t-1+\alpha 5 *$ TRi,t $-1 * H C R S t-1+\alpha 6 * H C R S t-1+X i, t-1 \pi$

$2+\mu t-1+\vartheta t+\gamma t+\varepsilon 2 i, t$

Where $\Delta L_{i,(t-1, t+4)}$ indicates the change in lending between the fourth period following the downgrade and one period preceding the downgrade. A longer lag is used here to account for persistence in loan extension over time compared to specification (1), where a more immediate effect of a downgrade on access to funding is expected. HCRS is a dummy that takes value 1 if a bank has higher than median reliance on rating-sensitive non-core funding defined above in the period preceding the downgrade. $\vartheta_{s}$ are bank $i$ headquarter's state fixed effects to control for variations in demand for credit across the US market. This specification is used to trace the impact of a downgrade on domestic bank lending to the decline in access to external funding documented through specification (1). ${ }^{16}$

We estimate specification (2) separately for banks with higher than median and banks with lower than median liquid assets buffers to assess whether a higher initial liquidity position allows the bank to better withstand the downgrade-related liquidity shock in terms of continuing to extend loans. ${ }^{17}$ We label banks with below median liquid assets buffer as having liquidity-constrained balance sheets, and those with above median liquid assets buffer as having liquidity-unconstrained balance sheets. The coefficient of interest is $\alpha_{3}$ is expected to be negative: a downgrade causes a higher decline in lending when wholesale markets are

\footnotetext{
${ }^{14}$ We classify as non-core any source of funding that falls outside the FDIC's definition of core funding as published in its Risk Management Manual of Examination Policies. The FDIC's definition was modified as of March 31, 2011, to exclude insured brokered deposits from core deposits. Since our sample covers Q1-2000 to Q4-2012, we keep brokered deposits, which represent a small portion of sources of funds, as part of core funding.

15 "Lloyds and RBS, in common with other banks, said they had ample liquidity reserves to handle any downgrade.... Not only have banks had months to prepare and diversify their funding away from rating sensitive sources ....Some banks have already begun aggressively to shrink their reliance on short-term funding in recent months, anticipating a downgrade ...UBS cut its funding in the commercial paper market by another \$13bn in the first quarter alone, bringing it down to \$38bn at the end of March. This is comfortably covered by its liquidity buffer of 23 per cent of its balance sheet. " Financial Times, May 212012

${ }^{16}$ While bank features such as profitability, asset quality or available capital are important determinants of bank lending decisions, we do not include them in equation 2 because these characteristics also determine rating downgrades, thereby leading to possible model misspecification.

${ }^{17}$ The next section defines liquid assets.
} 
under stress (co-insurance in interbank markets breaks down). It is also stronger when the downgraded bank holds a smaller buffer of liquid assets. This is likely to be true particularly for domestic lending and cross-border lending and perhaps less so for foreign lending (i.e. lending through foreign subsidiaries). Indeed, global banks may increase foreign lending when there is a macroeconomic crisis at home (Cetorelli and Goldberg, 2012a). ${ }^{18} \mathrm{We}$ therefore analyze foreign lending separately.

An important part of the analysis of foreign lending is to determine whether funding selfsufficiency in terms of reliance on local deposits to fund loans at foreign subsidiaries helps mitigate the effect of a parent downgrade on foreign lending. For this purpose, we consider two samples of foreign banks: a sample of foreign banks with higher than median deposits (scaled by foreign loans) and a sample of foreign banks with lower than median deposits. We expect the downgrade to have a stronger effect on foreign lending in the latter case as these banks have weaker funding self-sufficiency compared to the other group of foreign banks.

\section{Credit rating downgrade, internal funding, and bank lending}

Last, we use specification (1) to determine whether BHCs attempt to accommodate the downgrade shock through the activation of upstream and downstream internal liquidity support measures through centralized liquidity management. These measures include loans between the parent bank and its domestic and foreign subsidiaries as well as capital injections from the parent bank to its subsidiaries. The basic rationale for centralized liquidity management is that it helps maximize liquidity while reducing the cost of funds, which is most valued when liquidity is scarce like during a crisis. ${ }^{19}$ The financial stability benefits of centralized liquidity management have been acknowledged by an outspoken proponent of tighter capital and liquidity requirements for foreign subsidiaries.

"To be fair, the ability to move liquidity freely throughout a banking
group may have provided some financial stability benefits during the
crisis by enabling banks to respond to localized balance-sheet shocks
and dysfunctional markets in some areas (such as the interbank and
foreign exchange swap markets) and by transferring resources from
healthier parts of the group. " Daniel Tarullo, member of the Board of
Governors of the Federal Reserve System, November 2012

\footnotetext{
${ }^{18}$ Other empirical papers find that multinational banks that received liquidity and funding liquidity shocks during the global crisis operated a credit restriction in the host countries that was tighter than by domestic banks (e.g. De Haas and Lelyveld, 2011). A negative sign of $\alpha_{3}$ is consistent with this empirical finding.

${ }^{19}$ Stein (1997), Gertner, Scharfstein, and Stein (1994), and Stein (2002) rationalize the existence of internal flows as leading to a more efficient allocation of resources, whereas in Rajan, Servaes, and Zingales (2000) and Scharfstein and Stein (2000) the internal capital market is a managerial tool to mediate agency frictions existing within a firm. Houston, Marcus, and James (1997) provide empirical evidence that US bank holding companies establish internal capital markets to allocate scarce liquidity and capital among their various subsidiaries hence promoting lending. Compello (2002) finds that internal capital markets in financial conglomerates relax the credit constraints faced by smaller bank affiliates and that those markets lessen the impact of Fed policies on bank lending activity.
} 
When a crisis hits local markets, global banks can mitigate its adverse effects through a redistribution of funds from affiliates in excess of liquidity to affiliates in need of liquidity. Hass and van Lelyveld (2006) report that foreign banks are able to maintain credit supply during local crises if the parent bank is financially strong. However, internal funding activity of global banks can also be a direct channel for the international propagation of liquidity shocks. Cetorelli and Goldberg (2012a) document the role of cross-border internal fund flows in channeling monetary policy shocks across countries.

To explore whether the activation of internal support measures effectively helps mitigate the effect of a parent bank's downgrade on lending activity (or whether it contributes to propagating the shock within the bank network more widely), we use the following specification:

$$
\begin{aligned}
\Delta L_{i,(t-1, t+4)}= & c_{3}+\text { downgrade }_{i, t} * \Delta \text { internal support }_{i, t} * \rho_{1} \\
& +\rho_{2} * \text { downgrade }_{i, t}+\text { sinternal support } \\
& +\gamma_{t, t}+\rho_{3}+\vartheta_{t, t-1} \pi_{3}+\varepsilon_{3 i, t}
\end{aligned}
$$

Where internal support $_{i, t}$ is a vector of internal support measures between the parent bank and its subsidiary. If the activation of internal support measures, like the repatriation of funds from foreign offices, mitigates the effect of a downgrade on bank lending, $\rho_{1}$ (our coefficient of interest) should be positive and significant. ${ }^{20}$

\section{DATA}

This section provides a definition of key variables used in the econometric specifications and proceeds with a preliminary descriptive and statistical analysis of the data.

\section{A. Data Sources}

Our main source of information is the quarterly regulatory filings of listed US BHCs for the period Q1-2000 to Q4-2012. Through form FY-9C (Consolidated Financial Statements for Bank Holding Companies), US BHCs are required to report each quarter on their sources of funding, deposits and wholesale, which we classify as core and non-core funding. Core funding is expected to be credit rating-insensitive; it includes demand deposits, money market funds, insured time deposits, and insured brokered deposits. ${ }^{21}$ Non-core funding includes uninsured time deposits, deposits in foreign offices (foreign deposits) not covered by US deposit insurance, and wholesale funding in the form of fed funds purchased (unsecured short-term funding) and repurchase agreements (Repos).

From the same quarterly filings, we obtain total domestic lending and total foreign lending (i.e. lending through foreign affiliates), which we calculate as the difference between consolidated lending (line BHCK 2122) and domestic lending (line BHDM 2122).

\footnotetext{
${ }^{20}$ We believe that potential correlation between the need for liquidity support and subsidiary's features (such as profitability) is not an issue in our setup because our data is at the BHC level and not at the subsidiary level. ${ }^{21}$ The deposit insurance limit was USD 100K until October 2008. In October 2008 it was increased to USD $250 \mathrm{~K}$.
} 
Additional filings by parent banks only (form FY-9LP, Parent Company Only Financial Statements for Large Holding Companies) and calls reports (form 31) provide data on domestic and cross-border internal fund flows, i.e. fund flows between the parent bank and its domestic and/or foreign subsidiaries, respectively. From these filings, we compile information on internal support measures for which there is sufficient data and variability. These include net downstream loans from the parent to its bank subsidiaries and related BHCs (line BHCP 0533- (line BHCP 0467 + line BHCP 0539)), capital injections from the parent to its subsidiaries (line BHCP 3239), and net loans from the parent to its foreign subsidiaries (line RCON 2941 - line RCON 2163) which we refer throughout as net due $e^{22}$.

To determine whether a BHC has a liquidity constrained balance sheet, we calculate its asset share of liquid assets, which we define broadly as including cash and due from other depository institutions, fed funds sold, reverse repos, and total investment securities (held-tomaturity at amortized cost and available-for-sale at fair value). A narrower definition of liquid assets excludes investment securities other than claims on sovereign entities (US treasuries, US government agencies obligations, and securities issues by states and political subdivisions in the US).

For foreign subsidiaries, we determine whether their balance sheet is liquidity constrained depending on the value of the ratio of deposits to total loans. Foreign subsidiaries with a ratio of deposits to loans above the sample median are assumed to have liquidity unconstrained balance sheets and are referred to as being self-sufficient.

We match the balance sheet data with the Standard and Poor's long term rating (which we obtain from Datastream) using a common unique identifier for the top-tier BHC. We select Standard \& Poor's because it has a wider coverage than other credit rating agencies. After the matching, the sample includes 321 bank observations, of which 80 are downgraded banks. Hence, for some treated banks, there is more than one control bank.

A rating reflects the probability of repayment of a senior unsecured credit obligation of a bank, which is the most common type of credit in banks' liability structure. On average, banks are downgraded by one notch from $\mathrm{BBB}+$ to $\mathrm{BBB}$ over the entire sample period. Figure 1 shows the number of downgrades per quarter over the sample period. The majority of downgrades, 63 out of 80, occurs after and including Q4-2008. During the crisis, banks are downgraded by two notches on average from BBB+ to BBB-.

\section{B. Descriptive statistics}

Table 1 Panel A compares average observable characteristics of downgraded (treated) and non-downgraded (control) banks in our sample along with tests of differences in means in their basic characteristics. Treated and control banks have similar capitalization and size, but they are significantly different in terms of liquidity, asset quality, business model (loans/assets), funding model, and profitability. On average, prior to a credit rating downgrade, treated banks in our sample are significantly less liquid than control banks; they have a greater exposure to credit risk (higher loans to assets ratio) and a worse quality of loan portfolio (higher nonperforming loans ratio). Downgraded banks also rely significantly less

\footnotetext{
${ }^{22}$ A positive value of net due indicates that the parent owes money to its foreign subsidiaries, which is an indication of funds repatriation.
} 
on deposit funding compared to non-downgraded banks and they generate less income from the provision of traditional financial intermediation services (lower net interest margin). Panel B reports descriptive statistics for the deposit and other funding variables. Repos and uninsured time deposits are more important than other types of non-core funding. Fed funds and foreign deposits are non negligible. For core funding, the second largest source for banks after money market deposits is insured time deposits.

Next the table reports the average variation in each variable (our dependent variables) 1 quarter around a downgrade for the treated banks and the control banks computed as follows:

$$
\Delta y_{i,(t-1, t+1)}=\frac{y_{i, t+1}}{A_{i, t-1}}-\frac{y_{i, t-1}}{A_{i, t-1}}
$$

Where, for the deposits and funding variables, $y_{i, t-1}$ is $y_{i} 1$ quarter before the downgrade and $y_{i, t+1}$ is $y_{i}$ one quarter after the downgrade. And $A_{i, t-1}$ refers total assets before the downgrade.

From Panel A, uninsured deposits, including deposits in foreign offices, and unsecured wholesale funding decline on average for treated banks but not for the control banks, and the difference in means between treated and control banks is statistically significant (allowing for difference in variation between the two groups). In contrast, there is no statistical difference between treated and control banks' access to core funding following a downgrade. These statistical tests are just indicative as they do not allow for the effect of the downgrade to vary over time as conditions in wholesale markets deteriorate and they do not control for common and idiosyncratic drivers of the supply and demand for funding. This will be addressed in a multivariate context if the next section.

We check for the persistence of variations in funding sources over time by plotting the average variations 4 quarters around a downgrade in Figure 2. This allows to check whether variations in funding sources coincide with the occurrence of a downgrade and whether they are persistent; hence have the potential to impact lending. We observe in Figure 2 that, in the pre deposit insurance reform period, there is a persistent decline in uninsured time deposits immediately after a downgrade. The figure depicts a similar pattern for repos after the Lehman default. In contrast, core deposits increase persistently following a downgrade post Q4 2008, which indicates either that banks diversify away from rating sensitive sources of funding or that investors rush to safety. In Figure 3 to summarize we plot the cumulative variations pre and post Lehman using a spider chart and add internal funding support measures. Here we can observe a significant activation of capital injections and internal crossborder loans from the parent bank to its subsidiaries both before and after Lehman.

All in all, for the variables that display significant variations in funding sources, these variations coincide with the timing of the downgrade and are persistent, thereby motivating our focus on variations 1 quarter around the downgrade in the regression analysis. Panel B of Table 1 reports the summary statistics for lending activity. Variations 1 quarter around a downgrade are negative for downgraded banks for domestic lending and significantly different from variations at control banks. Variations of foreign lending are negative for the downgraded banks compared to non-downgraded banks, but the difference is not statistically significant. This univariate analysis is suggestive of a transmission of a downgrade-related liquidity shock to the real economy through the bank lending channel. The next section investigates this preliminary finding more rigorously using the regression framework described in section 2. 


\section{EMPIRICAL FINDINGS}

\section{A. Downgrade and Access to External Funding}

We first investigate the effect of a credit rating downgrade of BHCs on access to a variety of funding sources. We follow the FDIC's classification of core and non-core sources of funds and present our results using such a graduated scale for grading different funding sources that appear on the balance sheet.

Table 2 reports estimates of equation (1) for the full sample (Panel A), the sample before Q42008 (Panel B), and the sample after and including Q4-2008 (Panel C). The dependent variables are variations in different funding sources in percentage of total assets one quarter around a downgrade. In Panel A columns 1 through 10, we find that most forms of deposits and wholesale funding are insensitive to a downgrade except for fed funds (i.e. unsecured interbank funding) and foreign deposits, which are significantly lower for banks that are downgraded compared to control banks. These declines are also economically significant as they represent about $60 \%$ and $40 \%$ of a standard deviation on average, respectively, of variations in fed funds and foreign deposits.

In Panel B, we report the results for the period before the introduction of deposit insurance (October 2008). Here we find a significant decline in access to both insured (column 3 ) and non-insured time deposits (columns 5 and 6); however the reduction in non-insured deposits is larger in magnitude compared to insured time deposits ( 80 per cent of a standard deviation decline against 30 per cent of a standard deviation decline, respectively). Thus, prior to the demise of Lehman, time deposits seem to have been the most credit rating sensitive source of funding at BHCs. For banks with initial credit rating of A- or higher, a downgrade does not negatively affect their access to a variety of deposits and wholesale funding.

In Panel C, we report the results for the period after the extension of deposit insurance and after the Lehman default which triggered a collapse of interbank markets (Acharya and Merrouche, 2013; and Afonso, Kovner, and Schoar, 2011). We do not find significant variation in core sources of funding (columns 1 through 3), unlike banks' access to non-core funding. With the extension of the deposit insurance coverage, the impact of a downgrade on variations in uninsured deposit funding (which represents the bulk of non-core funding) remains negative albeit turning insignificant (columns 5 and 6). Access to foreign deposits that that are not covered by US deposit insurance, however, is significantly reduced (column 7) for banks that are downgraded compared to control banks. Further, in this period, a downgrade is associated with a statistically and economically significant decline in both repos (about $40 \%$ of a standard deviation, column 10) and fed funds (about $50 \%$ of a standard deviation, column 9). Interestingly, for banks that are downgraded but are initially rated Aand higher, their access to the repo funding market does not decline. In contrast, for unsecured funding (fed funds) the initial rating does not make a difference probably because most banks that have at all access to unsecured funding are rated A- and higher.

To summarize whether banks' access to non-core funding is impaired in stressed time, we run our main specification classifying sources of funds as core and non-core. The results presented in Table 3 confirm the significant decline in access to non-core funding after and including Q4-2008 but not before, indicating a greater sensitivity of investors to downgrades during turbulent times. More interestingly in Figure 4 we plot the estimated average effect of a downgrade for core and non-core funding for each credit rating and confirm that the largest effects coincide with a bank being downgraded from investment grade to speculative grade 
(from above $\mathrm{BBB}+$ to $\mathrm{BBB}$ or below) and falling below speculative grade (from $\mathrm{BB}$ to $\mathrm{B}$ ). The fact that the effect is non-linear is consistent with anecdotal evidence that wholesale lenders use rating triggers in loan covenants.

All in all, our findings confirm that non-insured and wholesale funds are credit-rating sensitive sources of funding. A credit rating downgrade is associated with a persistent decline in uninsured deposits and wholesale funding, which is both statistically and economically significant particularly when wholesale markets are under stress and co-insurance breaks down.

In the next section, we investigate whether a downgrade-triggered liquidity shock is transmitted to the real economy through the bank lending channel.

\section{B. Downgrade and Domestic Lending}

We examine the reduced form effect of a credit rating downgrade on domestic lending conditioning on the bank's liquidity position and reliance on none-core funding (Table 5) and separating liquidity constrained and unconstrained banks (Table 6). We run the analysis on the full sample and on four subsamples based on whether the banks have a high/low reliance on non-core funding and low/high own liquidity, all of which are split at the median. As mentioned in Section 3.2, we give particular consideration to foreign lending because foreign banks may expand credit abroad if the home country experiences a macroeconomic stress.

In Table 4 columns $1 \& 2$, we find that domestic lending declines significantly immediately following a downgrade both before and after and including Q4-2008. But this decline is not significant for top-rated banks $(\mathrm{TR}=1)$ whose access to external funding is less vulnerable to a downgrade event. To assess which downgraded banks drive the decrease in domestic lending, we run the analysis for four subsamples. In columns 3 through 6 , we split the sample at the median according to whether a bank is liquidity constrained and whether it relies more on credit rating sensitive (non-core) sources of funding. We find that the decline in lending increases in statistical and economic significance only for banks that both hold a lower than median buffer of liquid assets and banks that have a higher than median reliance on credit rating sensitive sources of funding (namely, uninsured time deposits and wholesale funding). This finding allows to firmly trace the decline in lending to the decline in access to external funding associated with a downgrade that we have documented in the previous section. Other liquidity constrained banks that have low reliance on non-core funding experience a reduction in lending, albeit insignificant (coefficient $=-9.411$ ), whereas the signs on non-liquidity constrained banks' coefficients turn positive but also insignificant irrespective of the bank's reliance on non-core funding.

In Table 5, we attempt to disentangle the role of the balance-sheet liquidity constraint versus reliance on credit rating sensitive sources of funding in amplifying the effect of the downgrade-related liquidity shock on bank lending. We estimate equation (2) separately for the sample of liquidity constrained banks (columns $1 \& 3$ ) and unconstrained banks (columns $2 \& 4$ ) on the full sample (columns $1 \& 2$ ) and the sample post-Q4 2008 (columns $3 \& 4$ ). We find that a credit rating downgrade is associated with a decline in lending only for banks that have a high reliance on credit-rating sensitive sources of funding $(\mathrm{HCRS}=1)$ and only in the post-Q4 2008 period. Hence, when banks self-insure their lending activity is not affected by a 
downgrade. In parallel, when they are liquidity constrained and co-insurance ${ }^{23}$ breaks down, lending activity declines substantially by about 2 standard deviations.

To sum up, we document that the decline in access to external funding associated with a credit rating downgrade translates into a significant decline in domestic lending for the most vulnerable banks. Therefore, despite the fact that the period after the Lehman default was marked by an unprecedented expansion of support measures from the Fed, the transmission of liquidity shocks to bank lending during this period is strongly linked to the extent to which banks were self-insuring by holding higher buffers of liquid assets.

\section{Downgrade and Foreign Lending}

In this section, we study the international transmission of a downgrade-triggered liquidity shock to foreign lending. The results are reported in Table 6 . In columns 1 and 2, we report coefficient estimates for the full sample and in columns 3 and 4 for the subsamples of funding constrained and unconstrained foreign subsidiaries in terms of being self-sufficient (below or above median reliance on local (host country) deposits to fund loans, respectively, for constrained and unconstrained foreign subsidiaries).

In column 1, a baseline specification that does not distinguish between the pre-Lehman and post-Lehman periods delivers insignificant estimates, but the results change after we introduce the dummy variable Post Q4-2008. In column 2, we find that the reduced-form effect of a downgrade on foreign lending is negative and significant statistically and economically before the crisis (about a 1 standard deviation decline in foreign lending one quarter around a downgrade). During the crisis, however, and for less vulnerable top-rated banks ( $T R=1)$, a downgrade does not trigger a significant decline in foreign lending. This finding lends support to the conjecture that when there is a macroeconomic crisis at home, global banks may choose to expand their lending abroad or at least sustain foreign investments as investment opportunities at home deteriorate.

When we split the sample between weak self-sufficient (constrained) and strong selfsufficient (unconstrained) foreign subsidiaries, we find that the decline in foreign lending is significant (and highly so) only for constrained subsidiaries (i.e. foreign subsidiaries with lower than median reliance on host country deposits). Thus, funding self-sufficiency of the foreign subsidiaries limits contagion across borders. In other words, when foreign subsidiary source funds independently of their domestic parent, they can sustain lending to the real economy in the host country when there is a crisis at home.

An additional way through which large banks can mitigate the impact of a liquidity shock is by activating internal liquidity support measures. In what follows, we explore the relevance of the activation of such support measures.

\section{Downgrade, Internal Funding Markets Activation, and Lending}

We first assess the impact of a credit rating downgrade on the activation of internal liquidity support measures giving special attention to the initial bank liquidity position, and we next investigate whether the activation of such support measures mitigates negative effects of a downgrade on domestic and foreign lending.

\footnotetext{
${ }^{23}$ That is, the ability of banks to meet funding needs by borrowing from other banks in a market.
} 
In Table 7, we show estimates of the reduced form effect of a downgrade on three forms of internal liquidity support measures across the full sample, before Q4-2008, and after and including Q4-2008: net downstream loans from the parent to its subsidiaries (column 1-4-7), capital injections from the parent to its subsidiaries (column 2-5-8), and net due from the domestic parent to its foreign subsidiaries (column 3-6-9). For the full sample and the crisis sample (i.e. after and including Q4-2008), the coefficient estimates are significant indicating that banks activate internal liquidity support measures in conjunction with a downgrade, but not so in the pre-crisis sample. During the crisis, top-rated domestic parents $(T R=1)$ significantly increase loans and capital injections to their subsidiaries (or related BHCs) and curb the repatriation of funds from foreign subsidiaries (net due falls). The reported point estimates are also economically significant when compared to the decline in external funding associated with a credit rating downgrade. However, downstream loans and capital injections measures are not activated at banks with a rating lower than A-, which are expected to be broadly more vulnerable to a downgrade.

In Table 8, we investigate the effect of a downgrade on the activation of internal support measures separately at banks with low or high liquid buffers. We find that the activation of internal support measures is significant only for banks that hold in aggregate low liquidity positions, i.e. they operate a liquidity constrained balance sheets (columns 1 to 3 ). We view these banks as being more likely to have in place centralized liquidity and capital management. The rationale for holding low liquid assets in aggregate is that banks expect to be able to manage liquidity more efficiently through a timely redistribution of liquid assets across the entire banking group, moving funds from parts that are in excess of liquidity to other parts that are in need of liquidity. From this table, under centralized liquidity management (low own liquidity), top-rated banks subject to a downgrade are more likely to provide more downstream loans to their subsidiaries, and a downgrade associates with lower funds lower funds repatriation back to the parent bank.

Having shown that banks activate internal support measures in response to a reduced access to external funding, we next assess whether the activation of such internal measures mitigates the previously documented adverse effect of a downgrade on domestic and foreign lending. We report in Table 9 coefficient estimates of equation 3 using variations in domestic lending (column 1) and foreign lending (column 2) as dependent variables. In column 1, we find that a higher increase in net due from the domestic parent to its foreign subsidiaries (or when the parent bank repatriates more funds from its foreign subsidiaries) in response to a downgrade at home contributes to curbing the downgrade's adverse effect on domestic lending. This effect is economically significant: a 1 standard deviation higher increase in net due reduces the effect of a downgrade on lower domestic lending by about 50 per cent. This result is consistent with our earlier finding from Table 8 that net due is the only form of internal funding measure that is activated at banks whose external funding sources are more vulnerable to a downgrade (i.e., for banks with $T R=0$ ). For foreign lending, we find that the adverse effect of a downgrade is tempered by capital injections. Finally, downstream loans from parent to subsidiary (which are small in our sample relative to other internal support measures) play an insignificant role in mitigating domestic and foreign lending.

In summary, we find that banks activate internal support measures in response to a liquidity shock that is triggered by a credit rating downgrade. However, in our sample, the activation of such measures is not large enough among the most vulnerable and constrained banks to offset the decline in external funding and to abate subsequent declines in bank lending. 


\section{Further TeStS ANd Robustness Checks}

In view of the fact that discussions on liquidity regulation are focusing on the definition of liquid assets, we investigate the sensitivity of our results to a narrower definition of liquid assets. We also explore the effect of a downgrade-triggered liquidity shock on alternative components of lending activity, and assess the robustness of our findings to including a wider set of control variables and to using an alternative estimation technique.

\section{A. Narrow definition of liquidity}

Instead of using the broad definition of liquidity as in the literature ${ }^{24}$, if we consider a narrower definition that excludes ABS, MBS, and other structured products, we find weaker results. In other words, a narrower definition of liquidity that integrates only US treasury securities and agency bonds and excludes non-sovereign and other investment securities fails to capture the actual capacity of a bank to mitigate the adverse effect of a liquidity shock on bank activities. One explanation is that downgraded banks are forced to deleverage more than non-downgraded banks (similar to what happened during the crisis), thereby increasing their ratio of narrow liquid assets to total assets to a level that is comparable to non-downgraded banks. Further, the share of US treasury securities and agency bonds is very low compared to the broader category that includes non-sovereign and other investment securities.

\section{B. Commercial and Industrial (C\&I) Lending and Cross-Border Lending}

We explore separately the transmission of the liquidity shock to C\&I and cross-border lending. Overall, we find the effects on domestic C\&I lending to be comparable to those on total domestic lending. When considering only foreign C\&I lending (which is a very small portion of foreign lending activity) all estimates turn insignificant. Further, we find crossborder lending to decline significantly (economically and statistically), and more so for banks more reliant on non-core funding, for liquidity constrained banks and during the period including and post Q4-2004.

\section{Controlling for Additional Observables and Alternative Matching Method}

We acknowledge that the observable characteristics of treated banks may explain significantly the likelihood of being downgraded. In this case, our estimates may be biased if these characteristics also explain directly (independently of whether the bank is downgraded) the demand for external (wholesale) funding and the speed of deleveraging: healthier banks are less likely to be downgraded; they would have a lower demand for external funding, in which case our estimates would be biased downward. And banks with higher asset quality may also have cheaper and greater access to public support ( Armantier, Krieger, and McAndrews, 2008). ${ }^{25}$

To check for this possibility, we re-estimated all the equations controlling for these additional (lagged) observable characteristics. Overall we found, as expected, that our results are comparable and the conclusions unchanged. ${ }^{26}$ Further, our findings are maintained when

\footnotetext{
${ }^{24}$ E.g Compello (2002) and Cetorelli and Goldberg (2012c).

${ }^{25}$ Ideally we want the estimated effect of a change in the credit rating on external funding to capture only a change in supply.

${ }^{26}$ The results are available upon request.
} 
applying the Abadie and Imbs (2011) estimator to account for the fact that treated and control banks have different observable characteristics. ${ }^{27}$

\section{CONCLuSION}

The recent financial crisis brought to the fore the importance of liquidity regulation and the need to ensure bank resilience during periods of liquidity crises. In this paper, we examine the effect of a liquidity shock triggered by a credit rating downgrade on the real economy through the lending channel. We focus on credit rating downgrades because they may rattle investor confidence and potentially lead to a loss in bank funding. We first assess the impact of a downgrade on a wide spectrum of external bank funding sources to evaluate their sensitivity to a rating change. We then examine the transmission of the downgrade-triggered funding liquidity shock to the bank lending portfolio both domestically and abroad. We also investigate whether the activation of internal support measures to reallocate funds from liquidity-surplus to liquidity-short affiliates helps mitigate the adverse effects of a downgradetriggered liquidity shock on bank lending.

The regression analyses confirm that a credit rating downgrade is associated with a simultaneous and persistent decline in access to non-core sources of deposits and to wholesale funding, which we identify as rating sensitive sources of funds. ${ }^{28} \mathrm{We}$ also find that this liquidity shock translates into a significant decline in domestic and foreign lending. We trace the reduction in lending to lower access to external funding by showing that the drop in lending is more severe for banks which rely more on credit rating sensitive sources of funding and for banks with liquidity constrained balance sheets. On the other hand, the activation of internal support measures in response to a downgrade contributes, albeit marginally, to curbing the effect of a downgrade on bank lending.

Our findings highlight the importance of maintaining liquid buffers at banks to better withstand liquidity shocks particularly during a crisis and maintain the flow of credit to the economy. However, agencies issues may discourage liquidity self-insurance as benefits from maintaining low buffers accrue contemporaneously and costs are deferred if borne at all. The study corroborates the need for liquidity regulation in view of minimizing the social costs of bail-outs and having to resort to the central bank lending facilities or to deposit insurance, thereby supporting the financial safety net. The new Basel III minimum liquidity requirements aim to promote self-insurance against liquidity shocks by adhering to a minimum Liquidity Coverage Ratio (LCR) and Net Stable Funding Ratio (NSFR). However, the new Basel III requirements treat intra-group transactions as third-party financial institution transactions in calculating the LCR, for example, thereby limiting the scope of liquidity risk to be centrally managed within a bank holding company (Basel Committee on Banking Supervision, 2013). ${ }^{29}$ Our paper shows that, for top-rated banks, there may be benefits from having in place a centralized liquidity management system to direct liquidity where it is most needed within a banking group and mitigate the effects of a liquidity shock. Thus, a liquidity ring-fencing proposal may need to cater for the financial strength of the banking institution rather than

\footnotetext{
${ }^{27}$ The idea of the Abadie and Imbs (2011) estimator is to first isolate treated banks and then, from the group of non-treated banks find observations that best match the treated ones on multiple dimensions (covariates). In our robustness check, we allow control banks to serve as matches more than once (which reduces the estimation bias but increases the variance) and allow perfect match on categorical variables (quarter and state).

${ }^{28}$ As a word of caution, given that authorities in both the United States (Dodd-Frank Act) and Europe (Regulation on Credit rating Agencies) have undertaken measures since the crisis to de-emphasize credit ratings, some of the results may hold less strongly in the future.

${ }^{29}$ In 2010, the UK Financial Services Authorities started requiring domestic banks to ring fence their liquidity.
} 
apply liquidity regulation uniformly to all, as banking groups derive cost benefits from having liquidity held centrally and directing it where it is most needed. ${ }^{30}$

Prior to the global financial crisis, cheap non-core funding had increased the risk profile of large banks by shifting resources to trading books, which with hindsight raised questions about the separation of commercial from investment banking activities (Gambacorta and van Rixtel, 2013). By showing that non-deposit and wholesale funding are rating sensitive and produce negative externalities to the real economy through the lending channel, the study supports a number of policy initiatives for structural bank regulation that have been recently considered or adopted, including the "Volcker rule", the Vickers Commission proposals, the Liikanen Report, as well as draft legislation in France and Germany. Specifically, our findings lend support to subsidiarization (placing high-risk bank activities in a separate legal entity) and ring-fencing proposals (structural separation of activities for retail banks). It also agrees with proposals to impose a levy on wholesale funding for large or too-big-to-fail banks that have increasingly relied on non-traditional sources of funding to expand their activities (Perotti and Suarez, 2009). ${ }^{31}$ We leave it for future research to examine the effectiveness of such macroprudential policies.

Finally, the paper underlines the importance of funding self-sufficiency at foreign banks in limiting negative (cross-border) spillovers from a parent bank's downgrade, thus upholding supervisory responses across countries to tighten local liquidity and/or capital requirements (Gambacorta and van Rixtel, 2013). While our data does not allow distinguishing between foreign branches and subsidiaries, banks that rely on wholesale market operations generally prefer to operate abroad through branches for greater flexibility to move funds within the banking group (Hoggarth, Hooley, and Korniyenko, 2013), an issue that we leave to future research.

\footnotetext{
${ }^{30}$ In this vein, the US Fed has recently published a joint notice that proposes to exclude intra-group transactions from both outflows and inflows in the calculation of the LCR (Federal Register, 2013). ${ }^{31}$ Post-crisis, US banks have shifted their funding patterns in favor of more customer deposits, which is likely to
reduce funding risks, albeit increasing cost of funding (Global Financial Stability Report, 2013).
} 


\section{References}

Abadie, A., and G. Imbens, 2011, "Bias-corrected matching estimators for average treatment effects", Journal of Business \& Economic Statistics 29, 1-11.

Acharya V. and B. Tuckman, 2013, "Unintended Consequences of LOLR Facilities: The Case of Illiquid Leverage" mimeo October 2013, presented at the 14th IMF Jacques Polak conference in honor of Stanley Fischer

Acharya V. and O. Merrouche, 2013, "Precautionary Hoarding of Liquidity and Inter-Bank Markets: Evidence from the Sub-prime Crisis", Review of Finance, 17(1), 107-160.

Afonso G., A. Kovner, and A. Schoar, 2011, "Stressed, not Frozen: The Federal Funds Market in the Financial Crisis", Journal of Finance, 66 (4), 1109-113.

Angeloni, C., and G.B. Wolff, 2012, "Are Banks Affected by Their Holdings of Government Debt?”, Bruegel Working Paper No. 07.

Arezki, R., B. Candelon, and A.N.R. Sy, 2011, "Sovereign Rating News and Financial Markets Spillovers: Evidence from the European Debt Crisis", IMF Working Paper No. 68.

Armantier, O., Krieger, S. and J. McAndrews, 2008, “The Federal Reserve's Term Auction Facility", Current Issues in Economics and Finance, 14(5), Federal Reserve Bank of New York.

Armentier O., E. Ghysels, A. Sarkar, and J. Shrader, 2011, "Stigma in Financial Markets: Evidence from Liquidity Auctions and Discount Window Borrowing during the Crisis”, Federal Reserve Bank of New York Staff Reports, Number 483, January 2011

Ashcraft, A., 2006, "New Evidence on the Lending Channel", Journal of Money, Credit and Banking, 38(3), 751-775.

Ashcraft, A., 2008, “ Are Bank Holding Companies a Source of Strength to their Banking Subsidiaries?", Journal of Money, Credit and Banking,40, 273-294.

Barba-Navaretti, G., G. Calzolari, M. Levi, and A. Pozzolo, 2010, "Multinational Banking in Europe: Financial Stability and Regulatory Implications Lessons from the Financial Crisis", Economic Policy, 25 (64), 703-753, October 2010.

Basel Committee on Banking Supervision, 2010, "Basel III: International Framework for Liquidity Risk Measurement, Standards, and Monitoring", Bank for International Settlements.

Basel Committee on Banking Supervision, 2013, "Basel III: The Liquidity Coverage Ratio and Liquidity Risk Monitoring Tools", January 2013.

Bailey, W., H. Li, C. Mao, and R. Zhong, 2003, 'Regulation Fair Disclosure and Earnings Information: Market, Analysts, and Corporate Responses', Journal of Finance, 58, 2487-2514. 
Campello M., 2002, "Internal capital markets in financial conglomerates: Evidence from small bank responses to monetary policy", Journal of Finance 57, 2773-2805.

Cetorelli N. and L. Goldberg, 2012a, "Banking Globalization and Monetary Transmission", Journal of Finance, 67, 1811-1843.

Cetorelli N., L. Goldberg, 2012b, "Follow the Money: Quantifying Domestic Effects of Foreign Bank Shocks in the Great Recession", American Economic Review, 102(3), 213-18.

Cetorelli N., L. Goldberg, 2012c, "Liquidity management of U.S. Global Banks: Internal Capital Markets in the Great Recession", Journal of International Economics, 88(2), 299-311.

Chava, S. and A. Purnanandam, 2011, "The Effect of Banking Crisis on Bank-Dependent Borrowers," Journal of Financial Economics, 99, 116-35.

De Haas R., and I. Lelyveld, 2010, "Internal capital markets and lending by multinational bank subsidiaries", Journal of Financial Intermediation 19, 1-25

Duarte, J., X. Han, J. Harford, and L. Young, 2008, 'Information Asymmetry, Information Dissemination and the Effect of Regulation FD on the Cost of Capital', Journal of Financial Economics, 87, 24-44.

Federal Register, 2013, 'Liquidity Coverage Ratio: Liquidity Risk Measurement, Standards, and Monitoring', November 2013.

Gambacorta, L., and A. van Rixtel, 2013, "Structural Bank Regulation Initiatives: Approaches and Implications", Monetary and Economic Department, Bank for International Settlements.

Gertner, R., D. Scharfstein, and J. Stein, 1994, "Internal versus external capital markets", Quarterly Journal of Economics, 109, 1211-1230.

Giannetti, M., L. Laeven, 2012a, "The Flight Home Effect: Evidence from the Syndicated Loan Market during Financial Crises”, Journal of Financial Economics, 104 (1), 2343.

Giannetti, M., L. Laeven, 2012b, "Flight Home, Flight Abroad and International Credit Cycles", American Economic Review, 102(3): 219-24.

Global Financial Stability Report, 2013, International Monetary Fund, October, Washington DC.

Hau H., S. Langfield, and D. Marquez-Ibanez, 2012, "Bank Ratings: What Determines their Quality?”, Economic Policy, Vol 28(74) (April 2013), 289-333.

Heider M., M. Hoerova and C. Holthausen, 2010, "Liquidity hoarding and interbank market spreads: the role of counterparty risk", mimeo ECB 
Hoggarth, G., J. Hooley, and Y. Korniyenko, 2013, "Which Way do Foreign Banks Sway? Evidence from the Recent UK Domestic Credit Cycle”, Bank of England Financial Stablity Paper No. 22.

Houston J., D. Marcus, and C. James, 1997, "Capital market frictions and the role of internal capital markets in banking?", Journal of Financial Economics 46, 135-164

Jorion, P., Liu, Z. and C. Shi, 2005, 'Informational effects of regulation FD: evidence from rating agencies', Journal of Financial Economics, 76, 309-30.

Liu, P., Seyyed, F.J. and S.D. Smith, 1999, 'The independent impact of credit rating changes - the case of Moody's rating refinement on yield premiums', Journal of Business Finance \& Accounting 26, 337-63.

Morgan, D. P., 2002, 'Rating Banks: Risk and Uncertainty in an Opaque Industry', American Economic Review 92, 874-88.

Perotti, E. and J. Suarez, 2009, 'Liquidity Risk Charges as a Macroprudential Tool', Center for Economic Policy Research, Policy Insight No.40

Popov, A. and Van Horen, N., 2013, "The impact of sovereign debt exposure on bank lending: Evidence from the European debt crisis”, DNB Working Paper No. 382/June 2013

Rajan, R., H. Servaes, and L. Zingales, 2000, "The cost of diversity: The diversification discount and inefficient investment", Journal of Finance 55, 35-80

Scharfstein, D., and J. Stein, 2000, "The dark side of internal capital markets: Divisional rentseeking and inefficient investment", Journal of Finance 55, 2537-2564

Schnabl, P., 2012, "The International Transmission of Bank Liquidity Shocks: Evidence from and Emerging Market", Journal of Finance 67(3), 897-932

Stein, J., 1997, "Internal capital markets and the competition for corporate resources", Journal of Finance 52, 111-133

Stein, J., 2002, "Information production and capital allocation: Decentralized vs hierarchical Firms", Journal of Finance 57, 1891-1921 
Table 1. Descriptive Statistics

The sample covers every quarter when a downgrade occurs in the period Q1-2000 to Q4-2012 including 80 downgraded banks and 241 control banks.

\section{Panel A. Comparison between downgraded (treated) and non-downgraded (control) banks}

This table reports average observable characteristics of treated and control banks. The equality test allows for unequal variance

\begin{tabular}{lccc}
\hline $\begin{array}{l}\text { Lagged (before downgrade) observable } \\
\text { characteristics }\end{array}$ & $\begin{array}{c}\text { Mean downgraded } \\
\text { banks }\end{array}$ & $\begin{array}{c}\text { Mean Non-downgraded } \\
\text { banks }\end{array}$ & $\begin{array}{c}\text { Test of difference p- } \\
\text { value }\end{array}$ \\
\hline \hline Tier 1 capital (leverage ratio) & 8.734 & 9.318 & 0.237 \\
Log total assets & 17.574 & 17.351 & 0.221 \\
Liquid assets/total assets & 0.256 & 0.332 & 0.000 \\
Narrow liquid assets/total assets & 0.093 & 0.126 & 0.015 \\
Loans/total assets & 0.653 & 0.579 & 0.000 \\
Non-performing loans/total loans & 0.042 & 0.023 & 0.000 \\
Deposits/loans & 0.934 & 1.078 & 0.017 \\
Net interest income/total assets & 0.017 & 0.020 & 0.035 \\
\hline
\end{tabular}

\section{Panel B. Funding structure}

This table shows the average structure of wholesale funding and deposits of the banks in our sample. Net downstream loans are net loans from the parent to its subsidiaries. Capital injection is the injection of capital by the parent to it subsidiaries. Net due is net loans from foreign subsidiaries to the domestic parent. All variables are taken from Bank Holding Companies (BHCs) regulatory fillings FY 9C and FY 9P (for the internal support variables) except net due which is taken from the calls reports form 031 and aggregated at the BHC level. The second and third columns report dollar values and the fourth column reports changes between quarter $\mathrm{t}+1$ and $\mathrm{t}-1$ in $\%$ of lagged total assets.

\begin{tabular}{r|r|r|r|r}
\hline & Full sample & Downgraded & Not downgraded \\
\hline \hline & Observations $\quad$ Median & Mean $\quad$ Standard deviation & Mean & Standard deviation \\
\hline \hline
\end{tabular}




\begin{tabular}{|c|c|c|c|c|c|c|}
\hline \multicolumn{7}{|l|}{ Core funding } \\
\hline Demand deposits & 316 & $372(1.47 \%)$ & -0.063 & 1.388 & 0.023 & 0.801 \\
\hline Money market deposits & 316 & $7716(30.6 \%)$ & 2.098 & 3.462 & 2.51 & 4.396 \\
\hline Insured time deposits & 316 & $2309(9.2 \%)$ & -0.643 & 2.217 & -0.243 & 2.218 \\
\hline $\begin{array}{l}\text { Insured Brokered deposits } \\
(<=100.000 \text { USD) }\end{array}$ & 320 & $60(0.23 \%)$ & -0.042 & 2.684 & -0.021 & 1.576 \\
\hline \multicolumn{7}{|l|}{ Non-core funding } \\
\hline Uninsured time deposits & 316 & $1749(6, . \%)$ & $-0.370^{*}$ & 1.7 & 0.153 & 1.959 \\
\hline Uninsured time deposits $<=1$ year & 301 & $1362(5.4 \%)$ & $-0.455^{\star}$ & 2.161 & 0.261 & 2.158 \\
\hline Foreign deposits & 318 & $116(0.46 \%)$ & $-0.370^{*}$ & 1.026 & 0.159 & 1.931 \\
\hline $\begin{array}{l}\text { Uninsured foreign time } \\
\text { deposits }<=1 \text { year }\end{array}$ & 300 & $38(0.15 \%)$ & -0.15 & 0.586 & -0.198 & 2.423 \\
\hline Fed funds & 289 & $144(0.57 \%)$ & $-0.378^{*}$ & 1.171 & 0.027 & 1.336 \\
\hline Repos & 289 & $816(3.24 \%)$ & -0.182 & 1.737 & 0.155 & 2.79 \\
\hline \multicolumn{7}{|l|}{ Internal support measures } \\
\hline Net downstream loans & 317 & 0 & -0.075 & 0.55 & -0.055 & 0.491 \\
\hline Capital injection & 318 & $1468(5.83 \%)$ & 0.142 & 0.881 & 0.328 & 1.291 \\
\hline Net due & 250 & $102(0.40 \%)$ & -0.057 & 1.938 & 0.464 & 2.948 \\
\hline
\end{tabular}

\section{Panel C. Lending}

This tables shows total and commercial and industrial (C\&I) lending in our sample. The data source is the BHCs regulatory fillings FY 9C. The second and third columns report dollar values and the fourth column reports changes between quarter $t+4$ and $t-1$ in $\%$ of lagged total assets.

\begin{tabular}{|c|c|c|c|c|c|c|c|}
\hline & Observations & Mean & Median & Mean & Standard deviation & Mean & $\begin{array}{l}\text { Standard } \\
\text { deviation }\end{array}$ \\
\hline & & Million USD & Million USD & Change & Change & Change & Change \\
\hline & & & & \multicolumn{2}{|c|}{ Downgrade } & \multicolumn{2}{|l|}{ Not downgraded } \\
\hline Domestic lending & 321 & 54424 & 13493 & $-4.121^{*}$ & 8.759 & 5.052 & 14.018 \\
\hline Foreign lending & 321 & 8155 & 0 & -0.414 & 1.686 & 0.071 & 4.264 \\
\hline
\end{tabular}




\section{Table 2. Downgrade and External Funding}

The table reports the result of estimating the following equation:

$$
\Delta y_{i,(t-1, t+1)}=c_{1}+\beta_{1} * \text { downgrade } e_{i, t}+\beta_{2} * \text { downgrade }_{i, t} * T R_{i, t-1}+X_{i, t-1} \pi_{1}+\mu_{t-1}+\gamma_{t}+\varepsilon_{1 i, t}
$$

Where Downgrade is a dummy that takes value 1 if a bank $i$ is downgraded. $\Delta y_{i}$ is the change in a deposit or funding variable between the quarter following and the quarter preceding the downgrade (scaled by total assets in the quarter preceding the downgrade). $T R$ is a dummy that takes value 1 if the bank is rated A- and higher in the quarter preceding the downgrade. $X_{i}$ includes the lagged log total assets, the lagged dependent variable, and the lagged level of the dependent variable, i.e $\Delta y_{i}$ and $y_{i}$ in the quarter preceding the downgrade (not shown). $\mu_{t-1}$ and $\gamma_{t}$ are initial rating (before the downgrade) and quarter fixed effects. We report results for the full sample and two subsamples, before Q4-2008, and after Q4-2008. Standard errors clustered by quarter are reported in parentheses. * $p<0.1 ; * * p<0.05 ; * * * p<0.01$

\section{Panel A. Full sample}

\begin{tabular}{|c|c|c|c|c|c|c|c|c|c|c|}
\hline & $\begin{array}{l}\text { Demand } \\
\text { deposits }\end{array}$ & $\begin{array}{c}\text { Money } \\
\text { market } \\
\text { deposits }\end{array}$ & $\begin{array}{l}\text { Insured time } \\
\text { deposits }\end{array}$ & $\begin{array}{l}\text { Insured } \\
\text { Brokered } \\
\text { deposits }\end{array}$ & $\begin{array}{l}\text { Uninsured } \\
\text { time } \\
\text { deposits }\end{array}$ & $\begin{array}{l}\text { Uninsured } \\
\text { time deposits } \\
<=1 \text { year }\end{array}$ & $\begin{array}{l}\text { Foreign } \\
\text { deposits }\end{array}$ & $\begin{array}{c}\text { Uninsured } \\
\text { foreign } \\
\text { time } \\
\text { deposits }<=1 \\
\text { year }\end{array}$ & Fed Funds & Repos \\
\hline & (1) & (2) & (3) & (4) & (5) & (6) & (7) & (8) & (9) & (10) \\
\hline Downgrade & $\begin{array}{l}-0.274 \\
(0.246)\end{array}$ & $\begin{array}{r}-0.585 \\
(0.692)\end{array}$ & $\begin{array}{r}0.074 \\
(0.366)\end{array}$ & $\begin{array}{r}0.471 \\
(0.357)\end{array}$ & $\begin{array}{r}-0.415 \\
(0.326)\end{array}$ & $\begin{array}{r}-0.343 \\
(0.420)\end{array}$ & $\begin{array}{r}-0.600 \\
(0.241)^{\star *}\end{array}$ & $\begin{array}{r}-0.124 \\
(0.119)\end{array}$ & $\begin{array}{l}-0.413 \\
(0.188)^{* *}\end{array}$ & $\begin{array}{l}-0.234 \\
(0.392)\end{array}$ \\
\hline Downgrade*TR & $\begin{array}{r}0.338 \\
(0.254)\end{array}$ & $\begin{array}{r}0.731 \\
(0.712)\end{array}$ & $\begin{array}{r}0.284 \\
(0.572)\end{array}$ & $\begin{array}{r}-0.309 \\
(0.589)\end{array}$ & $\begin{array}{r}0.692 \\
(0.360)^{*}\end{array}$ & $\begin{array}{r}0.351 \\
(0.477)\end{array}$ & $\begin{array}{r}-0.135 \\
(0.338)\end{array}$ & $\begin{array}{r}0.194 \\
(0.388)\end{array}$ & $\begin{array}{l}-0.117 \\
(0.258)\end{array}$ & $\begin{array}{l}0.456 \\
(0.498)\end{array}$ \\
\hline Constant & $\begin{array}{r}1.408 \\
(1.136) \\
\end{array}$ & $\begin{array}{l}-1.506 \\
(4.065)\end{array}$ & $\begin{array}{r}4.691 \\
(3.736) \\
\end{array}$ & $\begin{array}{r}-0.632 \\
(2.425)\end{array}$ & $\begin{array}{r}2.529 \\
(2.307) \\
\end{array}$ & $\begin{array}{r}5.254 \\
(2.683)^{*}\end{array}$ & $\begin{array}{l}-1.501 \\
(2.081)\end{array}$ & $\begin{array}{l}-1.623 \\
(2.034)\end{array}$ & $\begin{array}{c}2.066 \\
(1.563)\end{array}$ & $\begin{array}{l}-1.066 \\
(2.221)\end{array}$ \\
\hline $\begin{array}{l}\text { Observations } \\
R^{2}\end{array}$ & $\begin{array}{r}297 \\
0.18\end{array}$ & $\begin{array}{r}297 \\
0.26\end{array}$ & $\begin{array}{r}297 \\
0.22 \\
\end{array}$ & $\begin{array}{r}299 \\
0.30\end{array}$ & $\begin{array}{r}297 \\
0.24\end{array}$ & $\begin{array}{r}274 \\
0.23\end{array}$ & $\begin{array}{c}299 \\
0.20\end{array}$ & $\begin{array}{r}274 \\
0.27\end{array}$ & $\begin{array}{r}263 \\
0.22\end{array}$ & $\begin{array}{r}263 \\
0.22\end{array}$ \\
\hline
\end{tabular}




\section{Panel B. Before Q4-2008}

\begin{tabular}{|c|c|c|c|c|c|c|c|c|c|c|}
\hline & $\begin{array}{l}\text { Demand } \\
\text { deposits }\end{array}$ & $\begin{array}{c}\text { Money } \\
\text { market } \\
\text { deposits }\end{array}$ & $\begin{array}{l}\text { Insured } \\
\text { time } \\
\text { deposits }\end{array}$ & $\begin{array}{l}\text { Insured } \\
\text { Brokered } \\
\text { deposits }\end{array}$ & $\begin{array}{l}\text { Uninsured } \\
\text { time } \\
\text { deposits }\end{array}$ & $\begin{array}{c}\text { Uninsured } \\
\text { time deposits } \\
<=1 \text { year }\end{array}$ & $\begin{array}{l}\text { Foreign } \\
\text { deposits }\end{array}$ & $\begin{array}{c}\text { Uninsured } \\
\text { foreign time } \\
\text { deposits }<=1 \\
\text { year }\end{array}$ & Fed Funds & Repos \\
\hline & (1) & (2) & (3) & (4) & (5) & (6) & (7) & (8) & (9) & (10) \\
\hline Downgrade & $\begin{array}{r}0.010 \\
(0.400)\end{array}$ & $\begin{array}{r}-0.968 \\
(0.966)\end{array}$ & $\begin{array}{r}-0.735 \\
(0.353)^{*}\end{array}$ & $\begin{array}{r}-0.091 \\
(0.134)\end{array}$ & $\begin{array}{r}-1.377 \\
(0.717)^{*}\end{array}$ & $\begin{array}{r}-1.592 \\
(0.842)^{\star}\end{array}$ & $\begin{array}{c}-0.851 \\
(0.486)\end{array}$ & $\begin{array}{c}-0.487 \\
(0.435)\end{array}$ & $\begin{array}{l}-0.189 \\
(0.389)\end{array}$ & $\begin{array}{c}0.436 \\
(1.476)\end{array}$ \\
\hline Downgrade*TR & $\begin{array}{r}0.007 \\
(0.465)\end{array}$ & $\begin{array}{r}1.171 \\
(1.414)\end{array}$ & $\begin{array}{r}0.963 \\
(0.459)^{*}\end{array}$ & $\begin{array}{r}0.020 \\
(0.186)\end{array}$ & $\begin{array}{r}1.479 \\
(1.036)\end{array}$ & $\begin{array}{r}1.730 \\
(1.046)\end{array}$ & $\begin{array}{r}0.025 \\
(0.742)\end{array}$ & $\begin{array}{r}0.055 \\
(0.566)\end{array}$ & $\begin{array}{l}-0.557 \\
(0.868)\end{array}$ & $\begin{array}{l}-0.706 \\
(1.562)\end{array}$ \\
\hline Constant & $\begin{array}{r}2.354 \\
(1.763)\end{array}$ & $\begin{array}{r}-5.698 \\
(8.628)\end{array}$ & $\begin{array}{r}-0.943 \\
(1.883)\end{array}$ & $\begin{array}{r}-0.878 \\
(1.197)\end{array}$ & $\begin{array}{r}-1.198 \\
(3.355)\end{array}$ & $\begin{array}{r}3.843 \\
(5.048)\end{array}$ & $\begin{array}{r}0.466 \\
(2.459)\end{array}$ & $\begin{array}{r}0.235 \\
(2.729)\end{array}$ & $\begin{array}{c}3.707 \\
(3.989)\end{array}$ & $\begin{array}{c}1.668 \\
(2.992)\end{array}$ \\
\hline $\begin{array}{l}\text { Observations } \\
R^{2}\end{array}$ & $\begin{array}{r}113 \\
0.24\end{array}$ & $\begin{array}{r}113 \\
0.21\end{array}$ & $\begin{array}{r}113 \\
0.30\end{array}$ & $\begin{array}{r}112 \\
0.11\end{array}$ & $\begin{array}{r}113 \\
0.23\end{array}$ & $\begin{array}{r}114 \\
0.23\end{array}$ & $\begin{array}{c}114 \\
0.23\end{array}$ & $\begin{array}{r}114 \\
0.32\end{array}$ & $\begin{array}{r}76 \\
0.19 \\
\end{array}$ & $\begin{array}{r}76 \\
0.22 \\
\end{array}$ \\
\hline
\end{tabular}

Panel C. After and including Q4-2008

\begin{tabular}{|c|c|c|c|c|c|c|c|c|c|c|}
\hline & $\begin{array}{l}\text { Demand } \\
\text { deposits }\end{array}$ & $\begin{array}{c}\text { Money } \\
\text { market } \\
\text { deposits }\end{array}$ & $\begin{array}{l}\text { Insured time } \\
\text { deposits }\end{array}$ & $\begin{array}{l}\text { Insured } \\
\text { Brokered } \\
\text { deposits }\end{array}$ & $\begin{array}{l}\text { Uninsured } \\
\text { time } \\
\text { deposits }\end{array}$ & $\begin{array}{c}\text { Uninsured } \\
\text { time } \\
\text { deposits }<=1 \\
\text { year }\end{array}$ & $\begin{array}{l}\text { Foreign } \\
\text { deposits }\end{array}$ & $\begin{array}{c}\text { Uninsured } \\
\text { foreign time } \\
\text { deposits }<=1 \\
\text { year }\end{array}$ & Fed Funds & Repos \\
\hline & (1) & (2) & (3) & (4) & (5) & (6) & (7) & (8) & (9) & (10) \\
\hline Downgrade & $\begin{array}{r}-0.388 \\
(0.275)\end{array}$ & $\begin{array}{r}-0.689 \\
(0.932)\end{array}$ & $\begin{array}{r}0.708 \\
(0.438)\end{array}$ & $\begin{array}{r}0.773 \\
(0.489)\end{array}$ & $\begin{array}{r}-0.247 \\
(0.245)\end{array}$ & $\begin{array}{r}-0.079 \\
(0.328)\end{array}$ & $\begin{array}{r}-0.607 \\
(0.212)^{\star *}\end{array}$ & $\begin{array}{r}-0.438 \\
(0.262)\end{array}$ & $\begin{array}{l}-0.507 \\
(0.207)^{\star *}\end{array}$ & $\begin{array}{l}-0.695 \\
(0.293)^{\star *}\end{array}$ \\
\hline Downgrade ${ }^{\star} T R$ & $\begin{array}{r}0.573 \\
(0.307)^{*}\end{array}$ & $\begin{array}{r}0.681 \\
(0.842)\end{array}$ & $\begin{array}{r}0.035 \\
(0.872)\end{array}$ & $\begin{array}{r}-0.354 \\
(1.004)\end{array}$ & $\begin{array}{r}0.653 \\
(0.436)\end{array}$ & $\begin{array}{r}0.050 \\
(0.449)\end{array}$ & $\begin{array}{r}0.189 \\
(0.347)\end{array}$ & $\begin{array}{r}0.117 \\
(0.393)\end{array}$ & $\begin{array}{c}0.014 \\
(0.313)\end{array}$ & $\begin{array}{c}0.865 \\
(0.431)^{*}\end{array}$ \\
\hline Constant & $\begin{array}{r}0.616 \\
(1.362)\end{array}$ & $\begin{array}{l}-1.828 \\
(5.211)\end{array}$ & $\begin{array}{r}8.224 \\
(5.644)\end{array}$ & $\begin{array}{r}1.491 \\
(4.227)\end{array}$ & $\begin{array}{r}5.889 \\
(1.293)^{\star \star \star}\end{array}$ & $\begin{array}{r}7.329 \\
(3.389)^{*}\end{array}$ & $\begin{array}{l}-1.710 \\
(2.415)\end{array}$ & $\begin{array}{r}-5.833 \\
(3.773)\end{array}$ & $\begin{array}{c}1.941 \\
(1.329)\end{array}$ & $\begin{array}{l}-3.307 \\
(1.935)\end{array}$ \\
\hline $\begin{array}{l}\text { Observations } \\
R^{2}\end{array}$ & $\begin{array}{r}184 \\
0.18 \\
\end{array}$ & $\begin{array}{r}184 \\
0.30 \\
\end{array}$ & $\begin{array}{r}184 \\
0.22 \\
\end{array}$ & $\begin{array}{r}187 \\
0.32 \\
\end{array}$ & $\begin{array}{r}184 \\
0.31 \\
\end{array}$ & $\begin{array}{r}160 \\
0.28 \\
\end{array}$ & $\begin{array}{r}185 \\
0.26 \\
\end{array}$ & $\begin{array}{r}160 \\
0.49 \\
\end{array}$ & $\begin{array}{r}187 \\
0.39 \\
\end{array}$ & $\begin{array}{r}187 \\
0.51 \\
\end{array}$ \\
\hline
\end{tabular}




\section{Table 3. Downgrade and Bank Funding: Core versus Non-Core Funding}

The table reports the result of estimating the following equation:

$$
\Delta y_{i,(t-1, t+1)}=c_{1}+\beta_{1} * \text { downgrade } e_{i, t}+\beta_{2} * \text { downgrade }_{i, t} * T R_{i, t-1}+X_{i, t-1} \pi_{1}+\mu_{t-1}+\gamma_{t}+\varepsilon_{1 i, t}
$$

Where Downgrade is a dummy that takes value 1 if a bank $i$ is downgraded. $\Delta y_{i}$ is core or non-core funding between the quarter following and the quarter preceding the downgrade (scaled by total assets in the quarter preceding the downgrade). Core funding includes demand deposits, money market funds, insured time deposits, and insured brokered deposits; non-core funding include uninsured time deposits, deposits in foreign offices (foreign deposits) not covered by US deposit insurance, and wholesale funding in the form of fed funds purchased and repos. TR is a dummy that takes value 1 if the bank is rated A-and higher in the quarter preceding the downgrade. $X_{i}$ includes the lagged log total assets, the lagged dependent variable, and the lagged level of the dependent variable, i.e $\Delta y_{i}$ and $y_{i}$ in the quarter preceding the downgrade (not shown). $\mu_{t-1}$ and $\gamma_{t}$ are initial rating (before the downgrade) and quarter fixed effects. We report results for the full sample and two subsamples, before Q4-2008, and after Q4-2008. Standard errors clustered by quarter are reported in parentheses. $* p<0.1 ; * * p<0.05 ; * * * p<0.01$

\begin{tabular}{|c|c|c|c|c|c|c|}
\hline & \multicolumn{3}{|c|}{ Core funding } & \multicolumn{3}{|c|}{ Non-core funding } \\
\hline & $(1)$ & $(2)$ & (3) & $(4)$ & $(5)$ & $(6)$ \\
\hline & Full sample & $\begin{array}{c}\text { Before Q4- } \\
2008\end{array}$ & $\begin{array}{c}\text { After and } \\
\text { including Q4- } \\
2008\end{array}$ & Full sample & $\begin{array}{l}\text { Before Q4- } \\
2008\end{array}$ & $\begin{array}{c}\text { After and } \\
\text { including Q4- } \\
2008\end{array}$ \\
\hline Downgraded & $\begin{array}{l}-0.602 \\
(0.641)\end{array}$ & $\begin{array}{l}-1.422 \\
(1.051)\end{array}$ & $\begin{array}{l}-0.086 \\
(0.749)\end{array}$ & $\begin{array}{l}-1.207 \\
(0.375) * * *\end{array}$ & $\begin{array}{l}-0.353 \\
(2.302)\end{array}$ & $\begin{array}{l}-1.684 \\
(0.403) * * *\end{array}$ \\
\hline Downgraded $* T R$ & $\begin{array}{l}-0.461 \\
(1.225)\end{array}$ & $\begin{array}{c}1.813 \\
(1.854)\end{array}$ & $\begin{array}{l}-1.707 \\
(1.711)\end{array}$ & $\begin{array}{l}0.504 \\
(0.892)\end{array}$ & $\begin{array}{l}-1.283 \\
(2.336)\end{array}$ & $\begin{array}{l}1.250 \\
(1.392)\end{array}$ \\
\hline Constant & $\begin{array}{r}1.945 \\
(5.890) \\
\end{array}$ & $\begin{array}{l}-7.412 \\
(7.383) \\
\end{array}$ & $\begin{array}{c}8.532 \\
(9.000) \\
\end{array}$ & $\begin{array}{c}2.622 \\
(3.346) \\
\end{array}$ & $\begin{array}{l}-1.451 \\
(4.329)\end{array}$ & $\begin{array}{c}1.783 \\
(4.406)\end{array}$ \\
\hline Observations & 308 & 119 & 189 & 272 & 88 & 184 \\
\hline$R^{2}$ & 0.32 & 0.28 & 0.37 & 0.26 & 0.11 & 0.30 \\
\hline
\end{tabular}




\section{Table 4. Downgrade, Domestic Lending, and Liquidity-Constrained Balance Sheets I}

This table reports estimates of the effect of a downgrade on domestic bank lending for different samples: the full sample, and samples of banks with high or low own liquidity and high or low reliance on non-core sources of funding. The dependent variable is domestic lending measured as the change between a quarter preceding the downgrade and the fourth quarter posterior to the downgrade (See Table 1 Panel $\mathrm{C}$ for descriptives on domestic lending). Low and high own liquidity are two subsamples in which the lagged ratio of liquid assets to total assets is lower and higher than the median, respectively, separating liquidity-constrained from liquidityunconstrained banks. High and low non-core funding are two subsamples in which the reliance of the bank on non-core sources of funding (uninsured time deposits, deposits in foreign offices (foreign deposits) not covered by US deposit insurance, and wholesale funding in the form of fed funds purchased and repos, all scaled by total assets) is higher and lower than the median, respectively. $T R$ is a dummy that takes value 1 if the bank is rated A- and higher in the quarter preceding the downgrade. The specification allows for a differential effect for banks at the top end of the rating scale $(T R=1)$ and in the period following the Lehman bankruptcy and expansion of deposit insurance (Post Q4-2008). The regressions control for the lagged value of the dependent variable, its lagged level, headquarter's state fixed effect, initial rating fixed effect, quarter fixed effect, and lagged log assets (not shown). Standard errors clustered by quarter are reported in parentheses. $* p<0.1 ; * * p<0.05$; *** $p<0.01$

\begin{tabular}{|c|c|c|c|c|c|c|}
\hline & (1) & (2) & (3) & (4) & (5) & (6) \\
\hline & Full sample & Full sample & $\begin{array}{l}\text { High non-core } \\
\text { funding \& Low } \\
\text { own liquidity }\end{array}$ & $\begin{array}{l}\text { Low non-core } \\
\text { funding \& Low } \\
\text { own liquidity }\end{array}$ & $\begin{array}{l}\text { High non-core } \\
\text { funding \& High } \\
\text { own liquidity }\end{array}$ & $\begin{array}{l}\text { Low non-core } \\
\text { funding \& High } \\
\text { own liquidity }\end{array}$ \\
\hline Downgrade & $\begin{array}{r}-3.669 \\
(1.812)^{*}\end{array}$ & $\begin{array}{l}-10.148 \\
(5.639)^{\star}\end{array}$ & $\begin{array}{r}-8.679 \\
(4.139)^{* *}\end{array}$ & $\begin{array}{r}-9.411 \\
(9.567)\end{array}$ & $\begin{array}{r}1.660 \\
(24.865)\end{array}$ & $\begin{array}{r}4.141 \\
(3.724)\end{array}$ \\
\hline Downgrade*TR & $\begin{array}{r}2.743 \\
(2.808)\end{array}$ & $\begin{array}{r}9.801 \\
(6.843)\end{array}$ & $\begin{array}{r}6.110 \\
(11.446)\end{array}$ & $\begin{array}{r}5.388 \\
(10.330)\end{array}$ & $\begin{array}{r}-4.147 \\
(27.480)\end{array}$ & $\begin{array}{r}-1.429 \\
(4.087)\end{array}$ \\
\hline Downgrade*Post Q4-2008 & & $\begin{array}{r}7.819 \\
(6.355)\end{array}$ & & & & \\
\hline Downgrade*Post Q4-2008* TR & & $\begin{array}{l}-7.803 \\
(7.091)\end{array}$ & & & & \\
\hline Post Q4-2008*TR & & $\begin{array}{r}-6.494 \\
(5.936)\end{array}$ & & & & \\
\hline Constant & $\begin{array}{r}66.302 \\
(24.201)^{\star *}\end{array}$ & $\begin{array}{r}66.498 \\
(22.915)^{\star * *}\end{array}$ & $\begin{array}{r}72.216 \\
(62.110) \\
\end{array}$ & $\begin{array}{r}154.562 \\
(256.182) \\
\end{array}$ & $\begin{array}{r}358.768 \\
(336.674)\end{array}$ & $\begin{array}{r}32.326 \\
(29.891) \\
\end{array}$ \\
\hline $\begin{array}{l}\text { Observations } \\
R^{2}\end{array}$ & $\begin{array}{l}262 \\
0.43\end{array}$ & $\begin{array}{l}262 \\
0.44\end{array}$ & $\begin{array}{l}63 \\
0.80\end{array}$ & $\begin{array}{c}68 \\
0.78\end{array}$ & $\begin{array}{l}68 \\
0.66\end{array}$ & $\begin{array}{c}60 \\
0.92\end{array}$ \\
\hline
\end{tabular}


Table 5. Downgrade, Domestic Lending, and Liquidity-Constrained Balance Sheets II

$$
\begin{aligned}
\Delta L_{i,(t-1, t+4)}= & c_{2}+\alpha_{1} * \text { downgrade } i_{i, t}+\alpha_{2} * \text { downgrade }_{i, t} * \operatorname{TR}_{i, t-1}+\alpha_{3} * \text { downgrade }_{i, t} * \text { HCRS }_{t-1}+\alpha_{4} * \text { downgrade }_{i, t} * \\
& T R_{i, t-1} * H C R S_{t-1}+\alpha_{5} * T R_{i, t-1} * H C R S_{t-1}+\alpha_{6} * H C R S_{t-1}+X_{i, t-1} \pi_{2}+\mu_{t-1}+\vartheta_{t}+\gamma_{t}+\varepsilon_{2 i, t}
\end{aligned}
$$

The dependent variable is domestic lending measured as the change between a quarter preceding the downgrade and the fourth quarter posterior to the downgrade (See Table 1 Panel $\mathrm{C}$ for descriptives on domestic lending). We allow for the effect of a downgrade on domestic lending to vary with the bank's holding of liquid buffers, depending whether the lagged ratio of liquid assets to total assets is lower (Low own liquidity) or higher (High own liquidity) than the median. HCRS is a dummy that takes value one if the reliance of the bank on non-core sources of funding (uninsured time deposits, deposits in foreign offices (foreign deposits) not covered by US deposit insurance, and wholesale funding in the form of fed funds purchased and repos, all scaled by total assets) is higher than the median. $T R$ is a dummy that takes value 1 if the bank is rated A- and higher in the quarter preceding the downgrade. See Table 1 for a definition of all variables and descriptive statistics.. Columns $1 \& 2$ report the estimates for the full sample, and columns $3 \& 4$ for the post Q4 2008 period (each column for the sample of low and high own liquidity banks). The regressions control for the lagged value of the dependent variable, its lagged level, headquarter's state fixed effect, initial rating fixed effect, quarter fixed effect, and lagged log

\begin{tabular}{|c|c|c|c|c|}
\hline & $(1)$ & (2) & (3) & $(4)$ \\
\hline & \multicolumn{2}{|c|}{ Full sample } & \multicolumn{2}{|c|}{ After and including Q4-2008 sample } \\
\hline & Low own liquidity & High own liquidity & Low own liquidity & High own liquidity \\
\hline Downgrade & $\begin{array}{l}-2.535 \\
(3.293)\end{array}$ & $\begin{array}{l}-3.791 \\
(7.025)\end{array}$ & $\begin{array}{l}-1.251 \\
(2.510)\end{array}$ & $\begin{array}{l}-0.095 \\
(3333)\end{array}$ \\
\hline Downgrade* $T R$ & $\begin{array}{l}-0.267 \\
(4.443)\end{array}$ & $\begin{array}{c}10.269 \\
(11.347)\end{array}$ & $\begin{array}{l}2.298 \\
(4.742)\end{array}$ & $\begin{array}{l}3.569 \\
(6.070)\end{array}$ \\
\hline Downgrade* HCRS & $\begin{array}{l}-6.912 \\
(9.522)\end{array}$ & $\begin{array}{l}-7.737 \\
(7.913)\end{array}$ & $\begin{array}{l}-15.619 \\
(5.813)^{\star *}\end{array}$ & $\begin{array}{l}-9.167 \\
(6.435)\end{array}$ \\
\hline Downgrade $T R^{\star} H C R S$ & $\begin{array}{c}7.269 \\
(8.836)\end{array}$ & $\begin{array}{c}-0.533 \\
(13.655)\end{array}$ & $\begin{array}{c}9.654 \\
(7.831)\end{array}$ & $\begin{array}{c}8.850 \\
(7.441)\end{array}$ \\
\hline$T R^{\star} H C R S$ & $\begin{array}{l}-0.968 \\
(5.165)\end{array}$ & $\begin{array}{c}-2.311 \\
(12.183)\end{array}$ & $\begin{array}{l}-3.932 \\
(3.905)\end{array}$ & $\begin{array}{c}0.291 \\
(9.356)\end{array}$ \\
\hline HCRS & $\begin{array}{l}-1.407 \\
(6.109)\end{array}$ & $\begin{array}{c}5.010 \\
(11.214)\end{array}$ & $\begin{array}{c}4.215 \\
(2.505)\end{array}$ & $\begin{array}{c}4.654 \\
(7.433)\end{array}$ \\
\hline Constant & $\begin{array}{c}25.360 \\
(67.906)\end{array}$ & $\begin{array}{c}97.778 \\
(54.694)^{*}\end{array}$ & $\begin{array}{l}-73.586 \\
(40.181)^{*}\end{array}$ & $\begin{array}{c}41.201 \\
(65.550)\end{array}$ \\
\hline $\begin{array}{l}\text { Observations } \\
R^{2}\end{array}$ & $\begin{array}{c}131 \\
0.66\end{array}$ & $\begin{array}{l}128 \\
0.57\end{array}$ & $\begin{array}{r}102 \\
0.75\end{array}$ & $\begin{array}{l}73 \\
0.89\end{array}$ \\
\hline
\end{tabular}
assets (not shown). Standard errors clustered by quarter are reported in parentheses. ${ }^{*} p<0.1 ; * * p<0.05 ; * * * p<0.01 *$ 


\section{Table 6. Downgrade, Foreign Lending, and Self-Sufficiency}

The dependent variable is foreign lending measured as the change between a quarter preceding the downgrade and the fourth quarter posterior to the downgrade (See Table 1 Panel $\mathrm{C}$ for descriptives on foreign lending). We allow for the effect of a downgrade on foreign lending to vary with the foreign bank's self-sufficiency, depending whether reliance on local (host country) deposits (scaled by total foreign loans) lower (Weak self-sufficiency) or higher (Weak self-sufficiency) than the median. TR is a dummy that takes value 1 if the bank is rated A- and higher in the quarter preceding the downgrade. The regressions control for the lagged dependent variable, the lagged level of the dependent variable, headquarter's state fixed effect, initial rating fixed effect, quarter fixed effect, and lagged log assets (not shown). Standard errors clustered by quarter in parentheses. ${ }^{*} p<0.1 ; * * p<0.05 ; * * * p<0.01$

\begin{tabular}{|c|c|c|c|c|}
\hline & (1) & $(2)$ & (3) & (4) \\
\hline & Full sample & Full sample & $\begin{array}{l}\text { Weak self- } \\
\text { sufficiency }\end{array}$ & $\begin{array}{l}\text { Strong self- } \\
\text { sufficiency }\end{array}$ \\
\hline Downgrade & $\begin{array}{l}-1.618 \\
(0.948)\end{array}$ & $\begin{array}{r}-5.150 \\
(2.029)^{* *}\end{array}$ & $\begin{array}{c}-6.980 \\
(1.310)^{\star * *}\end{array}$ & $\begin{array}{l}-0.400 \\
(0.719)\end{array}$ \\
\hline Downgrade*TR & $\begin{array}{r}1.083 \\
(0.799)\end{array}$ & $\begin{array}{c}4.490 \\
(1.959)^{\star *}\end{array}$ & $\begin{array}{c}8.151 \\
(2.261)^{* * *}\end{array}$ & $\begin{array}{l}-0.232 \\
(0.639)\end{array}$ \\
\hline Downgrade*Post Q4-2008 & & $\begin{array}{c}4.044 \\
(1.778)^{\star *}\end{array}$ & $\begin{array}{c}4.765 \\
(1.793)^{\star \star}\end{array}$ & $\begin{array}{r}0.494 \\
(0.856)\end{array}$ \\
\hline Downgrade*Post Q4-2008* TR & & $\begin{array}{c}-3.663 \\
(1.854)^{*}\end{array}$ & $\begin{array}{c}-5.852 \\
(2.506)^{\star *}\end{array}$ & $\begin{array}{l}-0.552 \\
(0.813)\end{array}$ \\
\hline Post Q4-2008*TR & & -1.772 & -1.173 & 0.395 \\
\hline Constant & $\begin{array}{r}-11.430 \\
(7.075)\end{array}$ & $\begin{array}{r}(1.783) \\
-11.863 \\
(7.150)\end{array}$ & $\begin{array}{c}(1.846) \\
-24.888 \\
(13.337)^{\star}\end{array}$ & $\begin{array}{r}(0.565) \\
4.628 \\
(2.387)^{*}\end{array}$ \\
\hline $\begin{array}{l}\text { Observations } \\
R^{2}\end{array}$ & $\begin{array}{l}262 \\
0.44\end{array}$ & $\begin{array}{l}262 \\
0.45\end{array}$ & $\begin{array}{c}128 \\
0.67\end{array}$ & $\begin{array}{c}133 \\
0.57\end{array}$ \\
\hline
\end{tabular}


Table 7. Downgrade and Internal Funding I

This table report results from a regression similar to equation (1) in Table 2 but where the dependent variables are variations in indicators of internal liquidity support measures: net downstream loans from the parent to its subsidiaries (column 1-4-7), capital injections from the parent to its subsidiaries (column 2-5-8), and net due from the domestic parent to its foreign subsidiaries (column 3-6-9). Downgrade is a dummy that takes value 1 if a bank is downgrade and $T R$ is a dummy that takes value 1 if the initial rating of the bank is A- or higher. The regressions controls for the value of the lagged dependent variable, its lagged level, initial rating fixed effect, quarter fixed effect, and lagged log assets (not shown). Standard errors clustered by quarter in parentheses. * $p<0.1$; ** $p<0.05$; $* * * p<0.01$

\begin{tabular}{|c|c|c|c|c|c|c|c|c|c|}
\hline & \multicolumn{3}{|c|}{ Full sample } & \multicolumn{3}{|c|}{ Before Q4-2008 } & \multicolumn{3}{|c|}{ After and including Q4-2008 } \\
\hline & $\begin{array}{c}\text { Net } \\
\text { downstream } \\
\text { loans }\end{array}$ & $\begin{array}{c}\text { Capital } \\
\text { injection }\end{array}$ & Net due & $\begin{array}{c}\text { Net } \\
\text { downstream } \\
\text { loans }\end{array}$ & Capital injection & Net due & $\begin{array}{c}\text { Net } \\
\text { downstream } \\
\text { loans }\end{array}$ & Capital injection & Net due \\
\hline & (1) & (2) & (3) & (4) & (5) & (6) & (7) & (8) & (9) \\
\hline$\overline{\text { Downgrade }}$ & $\begin{array}{r}-0.069 \\
(0.075)\end{array}$ & $\begin{array}{r}-0.340 \\
(0.201)\end{array}$ & $\begin{array}{l}-0.518 \\
(0.383)\end{array}$ & $\begin{array}{r}0.044 \\
(0.079)\end{array}$ & $\begin{array}{r}0.057 \\
(0.153)\end{array}$ & $\begin{array}{c}0.426 \\
(0.615)\end{array}$ & $\begin{array}{r}-0.123 \\
(0.081)\end{array}$ & $\begin{array}{c}-0.454 \\
(0.247)^{*}\end{array}$ & $\begin{array}{l}-0.908 \\
(0.426)^{*}\end{array}$ \\
\hline Downgrade*TR & $\begin{array}{r}0.180 \\
(0.079)^{\star *}\end{array}$ & $\begin{array}{r}0.783 \\
(0.343)^{\star *}\end{array}$ & $\begin{array}{l}-0.445 \\
(0.877)\end{array}$ & $\begin{array}{r}-0.012 \\
(0.030)\end{array}$ & $\begin{array}{r}0.364 \\
(0.468)\end{array}$ & $\begin{array}{l}-1.251 \\
(1.108)\end{array}$ & $\begin{array}{r}0.185 \\
(0.089)^{*}\end{array}$ & $\begin{array}{r}1.060 \\
(0.464)^{\star *}\end{array}$ & $\begin{array}{l}-0.068 \\
(1.384)\end{array}$ \\
\hline Constant & $\begin{array}{r}-1.719 \\
(0.420)^{\star * \star}\end{array}$ & $\begin{array}{r}2.095 \\
(1.511)\end{array}$ & $\begin{array}{c}6.101 \\
(3.296)^{*}\end{array}$ & $\begin{array}{r}-0.708 \\
(0.374)^{*}\end{array}$ & $\begin{array}{l}-1.555 \\
(2.613)\end{array}$ & $\begin{array}{c}3.819 \\
(3.625)\end{array}$ & $\begin{array}{r}-2.126 \\
(0.651)^{\star * *}\end{array}$ & $\begin{array}{c}4.539 \\
(2.242)^{*}\end{array}$ & $\begin{array}{c}8.828 \\
(4.250)^{*}\end{array}$ \\
\hline $\begin{array}{l}\text { Observations } \\
R^{2}\end{array}$ & $\begin{array}{l}296 \\
0.40\end{array}$ & $\begin{array}{l}298 \\
0.17\end{array}$ & $\begin{array}{l}237 \\
0.18\end{array}$ & $\begin{array}{l}110 \\
0.19\end{array}$ & $\begin{array}{c}112 \\
0.24\end{array}$ & $\begin{array}{c}91 \\
0.29\end{array}$ & $\begin{array}{c}186 \\
0.47\end{array}$ & $\begin{array}{l}186 \\
0.19\end{array}$ & $\begin{array}{l}146 \\
0.23\end{array}$ \\
\hline
\end{tabular}


Table 8. Downgrade and Internal Funding II

This table reports results of the effect of a downgrade on internal support measures where we split the sample between banks with aggregate liquid assets above the median and banks with aggregate liquid assets below the median. Net downstream loans are from the parent to its subsidiaries (column 1 and 4), capital injections are from the parent to its subsidiaries (column 2 and 5), and net due are from the domestic parent to its foreign subsidiaries (column 3 and 6). See Table 1 for descriptive statistics on all variables. We allow for the effect of a downgrade on the activation of internal liquidity support measures to vary with the bank's holding of liquid buffers, depending whether the lagged ratio of liquid assets to total assets is lower (Low own liquidity) or higher (High own liquidity) than the median. TR is a dummy that takes value 1 if the bank is rated A- and higher in the quarter preceding the downgrade. The regressions control for lagged dependent variable, lagged level of the dependent variable, initial rating fixed effect, quarter fixed effect, and lagged $\log$ assets (not shown). Standard errors clustered by quarter in parentheses. ${ }^{*} p<0.1 ; * * p<0.05 ; * * * p<0.01$

\begin{tabular}{|c|c|c|c|c|c|c|}
\hline & \multicolumn{3}{|c|}{ Low own liquidity } & \multicolumn{3}{|c|}{ High own liquidity } \\
\hline & $\begin{array}{l}\text { Net downstream } \\
\text { loans }\end{array}$ & Capital injection & Net due & $\begin{array}{c}\text { Net } \\
\text { downstream } \\
\text { loans }\end{array}$ & Capital injection & Net due \\
\hline & (1) & $(2)$ & (3) & (4) & $(5)$ & $(6)$ \\
\hline Downgrade & $\begin{array}{l}-0.091 \\
(0.103)\end{array}$ & $\begin{array}{l}-0.381 \\
(0.383)\end{array}$ & $\begin{array}{l}-0.357 \\
(0.191)^{*}\end{array}$ & $\begin{array}{r}-0.148 \\
(0.174)\end{array}$ & $\begin{array}{l}-0.110 \\
(0.133)\end{array}$ & $\begin{array}{l}-0.164 \\
(0.720)\end{array}$ \\
\hline Downgrade*TR & $\begin{array}{l}0.266 \\
(0.110)^{\star *}\end{array}$ & $\begin{array}{c}1.419 \\
(0.899)\end{array}$ & $\begin{array}{l}-0.330 \\
(0.456)\end{array}$ & $\begin{array}{r}0.047 \\
(0.179)\end{array}$ & $\begin{array}{l}-0.231 \\
(0.209)\end{array}$ & $\begin{array}{c}0.541 \\
(2.528)\end{array}$ \\
\hline Constant & $\begin{array}{l}-2.407 \\
(0.972)^{\star *}\end{array}$ & $\begin{array}{c}5.029 \\
(2.888)^{*}\end{array}$ & $\begin{array}{l}-0.581 \\
(1.789)\end{array}$ & $\begin{array}{r}-0.741 \\
(0.389)^{*}\end{array}$ & $\begin{array}{c}1.417 \\
(1.480)\end{array}$ & $\begin{array}{l}11.013 \\
(3.937)^{\star *}\end{array}$ \\
\hline $\begin{array}{l}\text { Observations } \\
R^{2}\end{array}$ & $\begin{array}{c}141 \\
0.44\end{array}$ & $\begin{array}{c}141 \\
0.29\end{array}$ & $\begin{array}{c}109 \\
0.55\end{array}$ & $\begin{array}{c}130 \\
0.56\end{array}$ & $\begin{array}{c}131 \\
0.35\end{array}$ & $\begin{array}{l}106 \\
0.33\end{array}$ \\
\hline
\end{tabular}


Table 9. Downgrade, Internal Funding and Lending

$$
\begin{aligned}
& \Delta L_{i,(t-1, t+4)}=c_{3}+\text { downgrade }_{i, t} * \Delta \text { internal support }_{i, t} * \rho_{1}+\rho_{2} * \text { downgrade }_{i, t} \\
& +\Delta \text { internal support }{ }_{i, t} * \rho_{3}+X_{i, t-1} \pi_{3}+\mu_{t}+\gamma_{t}+\vartheta_{t}+\varepsilon_{3 i, t}
\end{aligned}
$$

This table report a test of the hypothesis that the activation of internal support measures help mitigate the impact of a downgrade on lending. This is done by interacting the indicator variable downgrade with the changes in internal support measured that occur between the quarter immediately preceding and following a downgrade. Net downstream loans are from the parent to its subsidiaries, capital injections are from the parent to its subsidiaries, and net due are from the domestic parent to its foreign subsidiaries. See Table 1 for a definition and summary statistics of variables. The regressions control for lagged dependent variable, lagged level of the dependent variable, headquarter's state fixed effect, initial rating fixed effect, quarter fixed effect, and lagged log assets (not shown). Standard errors clustered by quarter in parentheses. $* p<0.1 ; * *$ $p<0.05 ; * * * p<0.01$

\begin{tabular}{lcc}
\hline & Domestic lending & Foreign lending \\
\hline Downgrade & $(1)$ & $(2)$ \\
\hline Downgrade*Net downstream loans & -3.602 & -1.369 \\
& $(1.712)^{\star *}$ & $(0.512)^{\star *}$ \\
Downgrade ${ }^{\star}$ Capital injection & 4.231 & -0.425 \\
& $(4.499)$ & $(2.407)$ \\
Downgrade Net due & -0.412 & 0.678 \\
& $(1.187)$ & $(0.387)^{\star}$ \\
Net downstream loans & 0.909 & 0.018 \\
& $(0.509)^{*}$ & $(0.144)$ \\
Capital injection & 0.369 & 2.381 \\
& $(5.229)$ & $(2.230)$ \\
Net due & 1.971 & -0.175 \\
& $(1.391)$ & $(0.253)$ \\
Constant & -0.330 & 0.068 \\
& $(0.257)$ & $(0.048)$ \\
Observations & 113.405 & -0.275 \\
$R^{2}$ & $(45.328)^{\star *}$ & $(5.065)$ \\
\hline
\end{tabular}


Figure 1. Number of credit rating downgrades by quarter

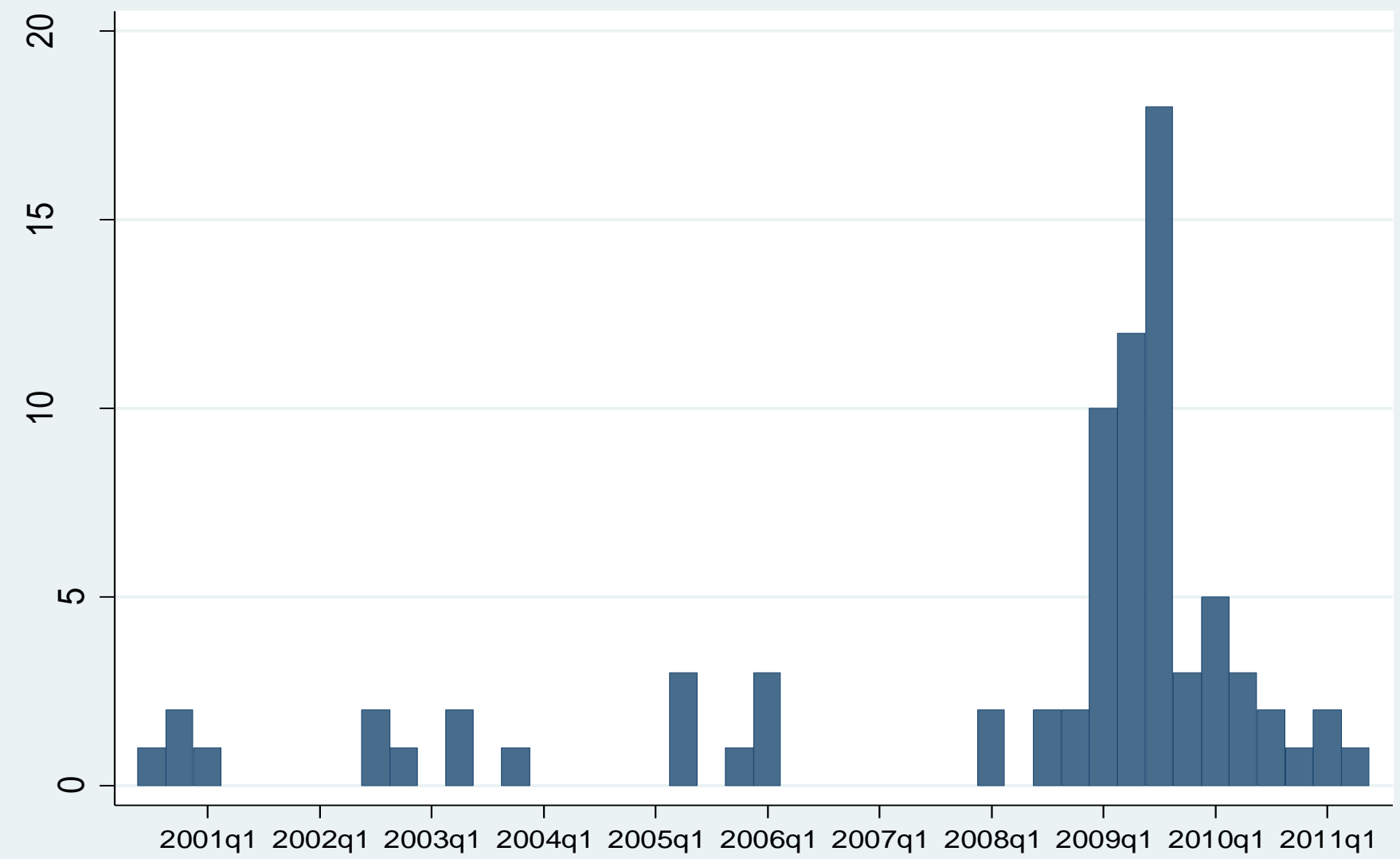

Source: Bloomberg 
Figure 2. Average deposits and funding 4 quarters around a downgrade pre and post Q4-2008

All variables are scaled by total assets. In October 2008 the US authorities raised the deposit insurance coverage from USD 100K to $250 \mathrm{~K}$.
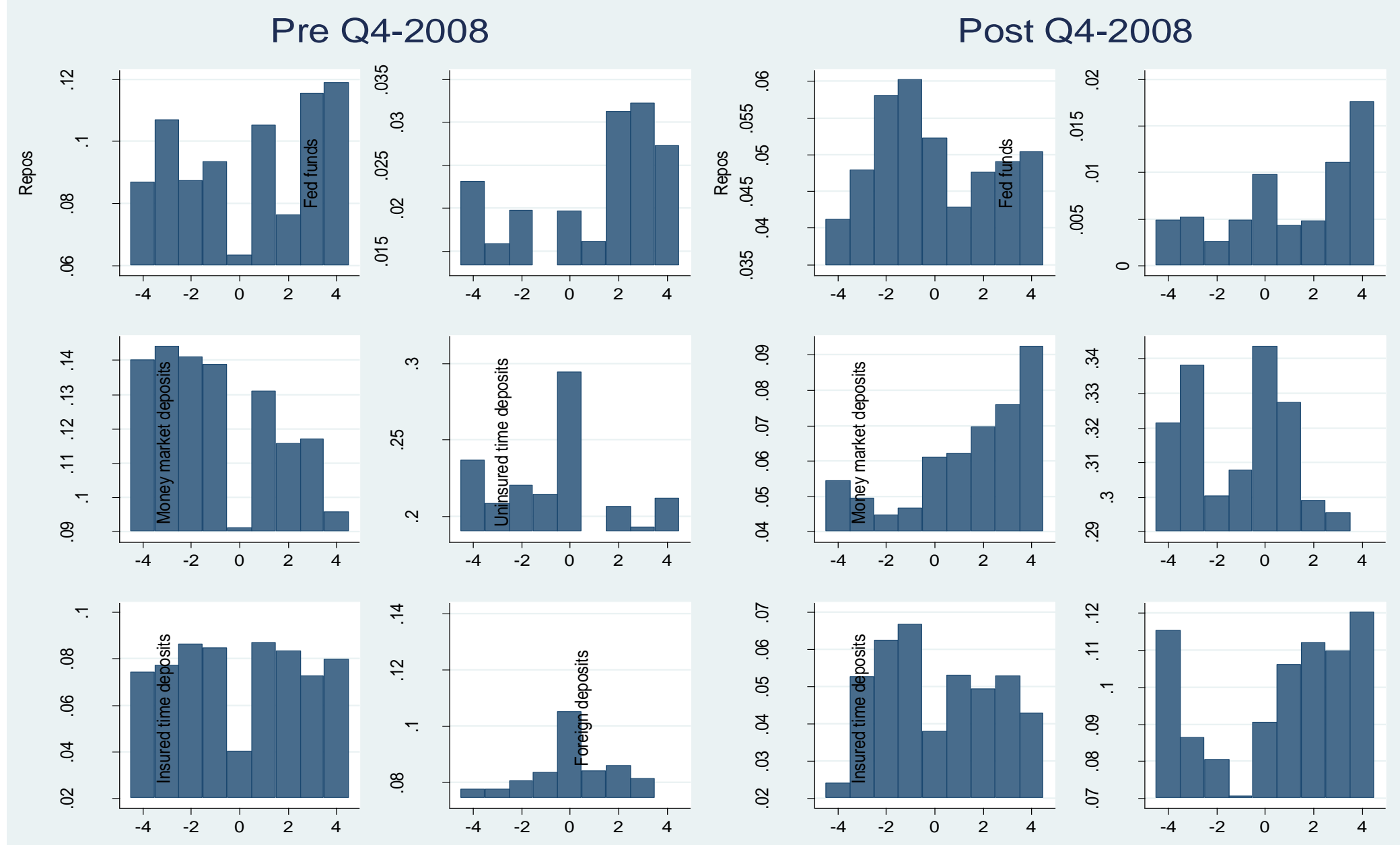
Figure 3. Cumulative sum of changes in external and internal funding 4 quarters around a downgrade ( 2 before, 2 after), pre and post Q4-2008

Pre Q4-2008

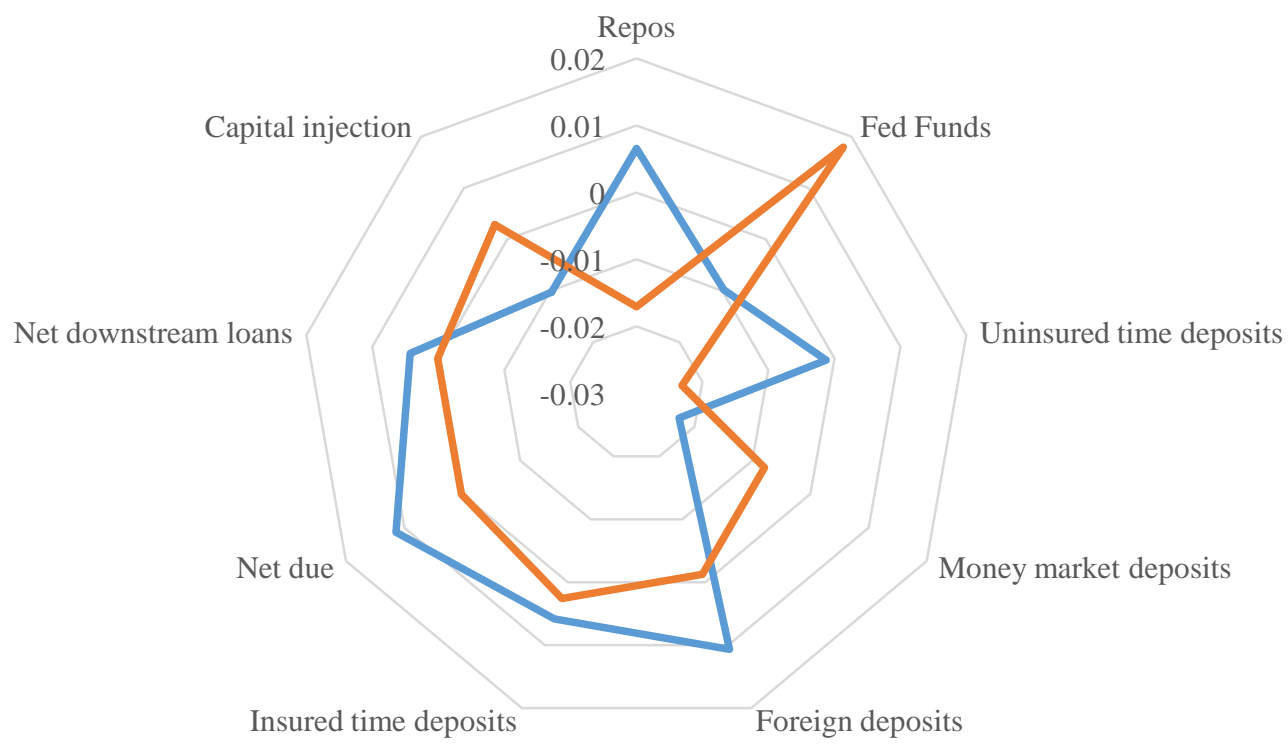

Before downgrade $\longrightarrow$ After downgrade

Post Q4-2008

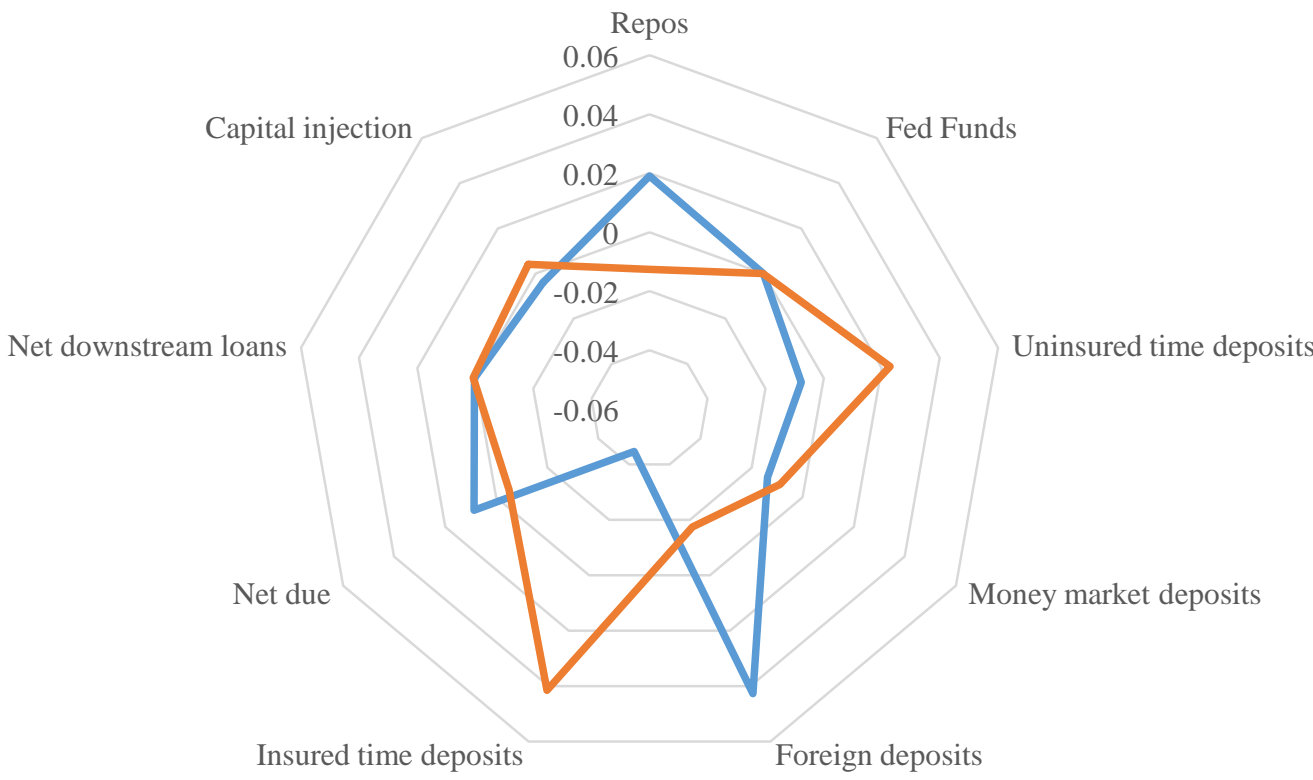
After downgrade 
Figure 4. Average effect of a credit rating downgrade on core and non-core funding for at different credit ratings

Note: The dashed lines are 95\% significance intervals. Solid lines are average estimated effects. Core funding includes demand deposits, money market funds, insured time deposits, and insured brokered deposits; non-core funding include uninsured time deposits, deposits in foreign offices (foreign deposits) not covered by US deposit insurance, and wholesale funding in the form of fed funds purchased and repos.

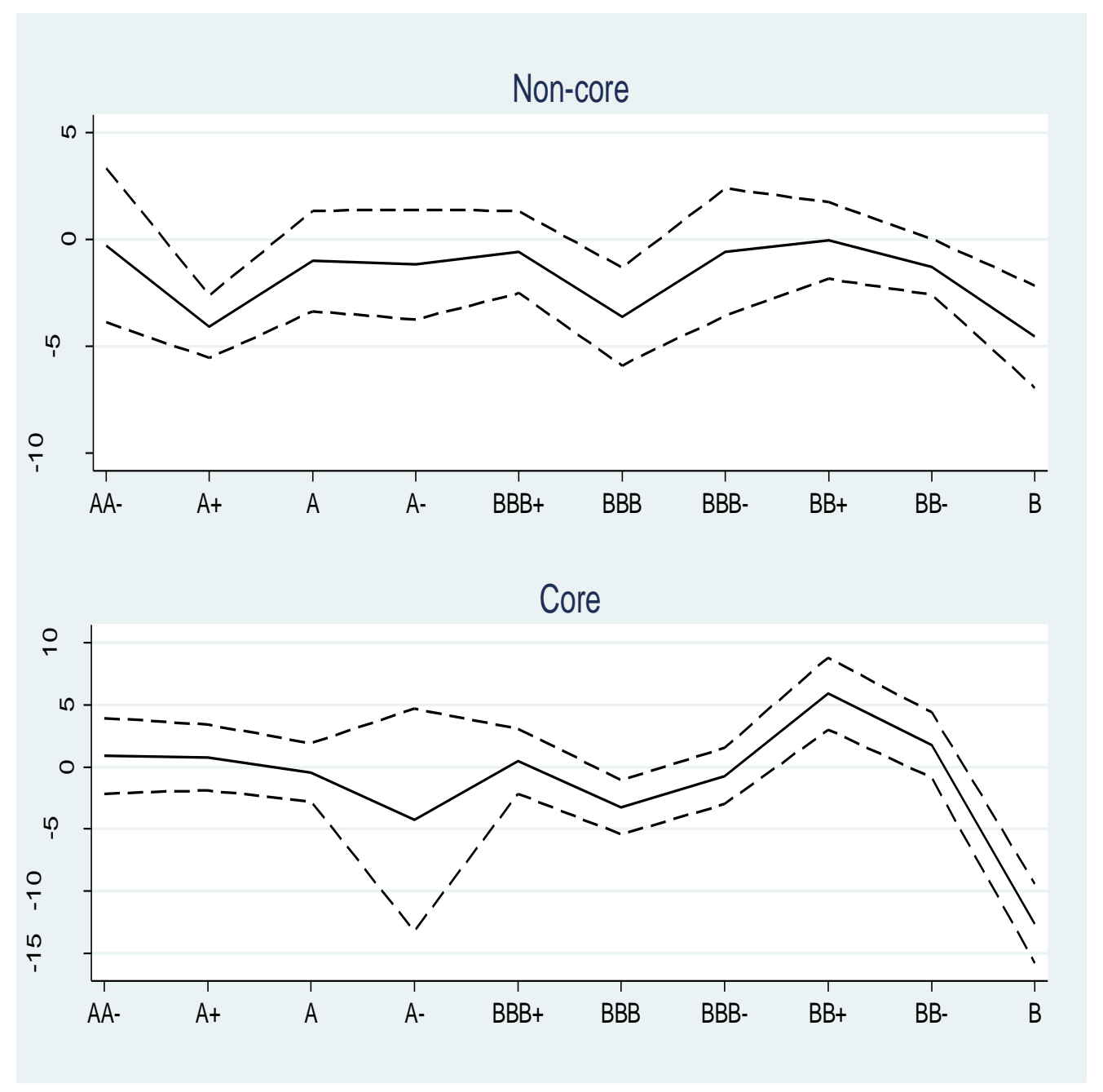

